Check for updates

Cite this: RSC Adv., 2020, 10, 22712

\title{
Zinc(II) triazole meso-arylsubstituted porphyrins for UV-visible chloride and bromide detection. Adsorption and catalytic degradation of malachite green dye $\uparrow$
}

\author{
Mouhieddinne Guergueb, ${ }^{a}$ Jihed Brahmi, ${ }^{a}$ Soumaya Nasri, ${ }^{\text {ab }}$ Frédérique Loiseau, ${ }^{c}$ \\ Kaïss Aouadi, ${ }^{d}$ Vincent Guerineau, ${ }^{e}$ Shabir Najmudin (D) ${ }^{f}$ and Habib Nasri (D) ${ }^{a}$
}

\begin{abstract}
Three new triazole meso-arylporphyrins $(4 a-c)$ were synthesized by the copper( () -catalyzed azide alkyne cycloaddition (CUAAC) "click" reaction in high yield. The corresponding zinc(॥) coordination compounds $(5 a-c)$ have also been prepared. All $4 a-c$ and $5 a-c$ porphyrin species were fully characterized by elemental analysis, electrospray ionization and MALDI-TOF mass spectrometry, infrared spectroscopy, proton nuclear magnetic resonance, UV-visible, fluorescence and cyclic voltammetry. The zinc(॥) $5 a-c$ complexes have been tested as detectors for $\mathrm{Cl}^{-}$and $\mathrm{Br}^{-}$anions. UV-visible titrations reveal that these host systems exhibit strong anion binding affinities. The efficiency of the adsorption of the malachite green dye (MG) dye on the $4 a-c$ free base porphyrins and the corresponding zinc(II) complexes $5 a-c$ was investigated by a kinetic study using these synthetic porphyrin derivatives as adsorbents. The use of our triazole $\mathrm{Zn}(\|)$ complexes in the catalytic degradation of the MG dye is the first example where a metalloporphyrin is involved in the MG dye decolorization reaction. The degradation reactions were carried out using an ecological oxidant $\left(\mathrm{H}_{2} \mathrm{O}_{2}\right)$, where the efficiency of the decolorization has been characterized by UV-visible spectroscopic analysis. Several factors affecting the degradation phenomenon have been studied. The energetic parameters concerning the degradation process have also been determined.
\end{abstract}

Received 5th April 2020

Accepted 3rd June 2020

DOI: $10.1039 / \mathrm{dOra03070h}$

rsc.li/rsc-advances

\section{Introduction}

In the fields of chemistry, biochemistry and material sciences, porphyrins and metalloporphyrins have been extensively studied due to their vast range of potential applications such as: photodynamic therapy, catalysis, ${ }^{1,2}$ as building blocks, ${ }^{3}$ in artificial photosynthetic systems ${ }^{4}$ and as sensors. ${ }^{5,6}$ The chemical modifications at the meso positions of porphyrins give rise to a large number of porphyrin derivatives with unique electronic

${ }^{a}$ University of Monastir, Laboratoire de Physico-chimie des Matériaux, Faculté des Sciences de Monastir, Avenue de l'environnement, 5019 Monastir, Tunisia. E-mail: hnasri1@gmail.com; Habib.Nasri@fsm.rnu.tn; Fax: +216 73500278

${ }^{b}$ Department of Chemistry, College of Science Al-Zulfi, Majmaah University, Saudi Arabia

'Département de Chimie Moléculaire, Université Grenoble Alpes, 301 rue de la Chimie, CS 40700, 38058 Grenoble Cedex 9, France

${ }^{d}$ Department of Chemistry, College of Science, Qassim University, Buraidah 51452, Saudi Arabia

${ }^{e}$ Institut de Chimie des Substances Naturelles CNRS, Avenue de la Terrasse, F-91198 Gif-sur-Yvette, France

${ }^{f}$ Randall Centre for Cell and Molecular Biophysics, Faculty of Life Sciences and Medicine, King's College, 3rd Floor New Hunt's House, London SE1 1UL, UK

$\dagger$ Electronic supplementary information (ESI) available. See DOI: 10.1039/d0ra03070h and optical properties. Phosphines, pyridines, imidazoles and crown ethers, to name a few, have been used to functionalize meso-arylporphyrins. ${ }^{7-10}$ Since its introduction in 2001 by Sharpless et al., ${ }^{11}$ the copper catalyzed azide-alkyne cycloaddition (CuAAC) known as "click chemistry" has been widely used to link moieties together in a very efficient and reliable way to prepare new functionalized meso-arylporphyrins. Beer et al., ${ }^{12,13}$ reported the synthesis and the characterization of several functionalized meso-porphyrins such as the "porphyrin-cage" and the tetra-triazole-appended "picket-fence" zinc(II) coordination compounds. These species were prepared to be tested as receptors for halide and other inorganic salts. Thus, the aim is to investigate the role of various substituents at the porphyrin meso-positions for receptor efficiency.

Interestingly, porphyrins and metalloporphyrins have been tested effectively in the degradation of chemical dyes. Indeed, these species constitute a large part of water pollutants due to the sewage discharge containing carcinogenic and chronically toxic organic dyes, ${ }^{14}$ which are extensively used in textile, printing and photographic industries. During the late decade, several free bases porphyrins have been used as catalysts in presence of $\mathrm{TiO}_{2}$, in the photocatalytic degradation of dyes, e.g. the meso-arylporphyrins substituted by phenyl carboxylic acid 
groups and di-tert-butyl-substituted phenyl rings have been used in the degradation of the methylene blue (MB) dye. ${ }^{15}$ Metal porphyrins such as the manganese(III) metalloporphyrin based polymers have also been used in the methylene blue dye (MB) degradation in an aqueous solution of hydrogen peroxide. ${ }^{16} \mathrm{We}$ also reported the use of two 4-cyanopyridine-cobaltousporphyrin complexes type $\left[\mathrm{Co}^{\mathrm{II}}(\mathrm{Porph})(4-\mathrm{CNpy})\right]$ (Porph $=$ meso-tetrakis(para-methoxyphenyl)porphyrinato and meso-tetra(para-chlorophenyl)porphyrin) in the same MB dye degradation in presence of $\mathrm{H}_{2} \mathrm{O}_{2} \cdot{ }^{17}$ In 2018 , we reported the catalytic degradation of the Calmagite dye using an aqueous solution of $\mathrm{H}_{2} \mathrm{O}_{2}$ with the (4,4'-bipyridine)[(tetrakis(ethyl-4(4-butyryl)oxyphenyl)porphyrinato)]zinc(II) complex. ${ }^{18}$

Among dyes, the malachite green (MG) dye, with the formula $\left[\mathrm{C}_{6} \mathrm{H}_{5} \mathrm{C}\left(\mathrm{C}_{6} \mathrm{H}_{4} \mathrm{~N}\left(\mathrm{CH}_{3}\right)_{2}\right)_{2}\right] \mathrm{Cl}$ (Scheme 1) is widely used in the textile and paper industry. The $\left[\mathrm{C}_{6} \mathrm{H}_{5} \mathrm{C}\left(\mathrm{C}_{6} \mathrm{H}_{4} \mathrm{~N}\left(\mathrm{CH}_{3}\right)_{2}\right)_{2}\right]^{+}$cation which gives the very intense green color to this dye exhibits a very strong absorption band at $621 \mathrm{~nm}$.

During the past two decades, reports on the enduring carcinogenic and mutagenic characteristics of MG dye have increased. ${ }^{19}$ Since 2000 , the MG dye has been listed as a priority chemical for carcinogenicity assessment by the U.S. Food and Drug Administration. ${ }^{20}$ However, due to its efficacy and low cost, it is still used in many countries. Therefore, many treatment technologies have been applied to decolorize MG from aqueous medium. ${ }^{21}$

Here, we describe the preparation of three new substituted meso-arylporphyrins using the "click chemistry" strategy and their zinc(II) corresponding complexes namely: the meso-tetrakis(3-methoxy-4-((1-phenyl-1H-1,2,3-triazol-4-yl)methoxy) phenyl)porphyrin (4a) $\left[\mathrm{H}_{2}\left(\mathrm{~T}_{\mathrm{AzP}}-\mathrm{HVP}\right)\right]$, the meso-tetrakis(4-((1-(4chlorophenyl)-1H-1,2,3-triazol-4-yl)methoxy)-3-methoxyphenyl) porphyrin (4b) $\left[\mathrm{H}_{2}\left(\mathrm{~T}_{\mathrm{AzP}}-\mathrm{ClVP}\right)\right]$, and the meso-tetrakis(4-((1-(4iodinephenyl)-1H-1,2,3-triazol-4-yl)methoxy)-3-methoxyphenyl) porphyrin (4c) $\left[\mathrm{H}_{2}\left(\mathrm{~T}_{\mathrm{AzP}}-\mathrm{IVP}\right)\right]$ and the corresponding $\mathrm{zinc}(\mathrm{II})$ metalloporphyrins: 5a-c with the formulas $\left[\mathrm{Zn}\left(\mathrm{T}_{\mathrm{AzP}}-\mathrm{HVP}\right)\right]$, $\left[\mathrm{Zn}\left(\mathrm{T}_{\mathrm{AzP}}-\mathrm{ClVP}\right)\right]$ and $\left[\mathrm{Zn}\left(\mathrm{T}_{\mathrm{AzP}}-\mathrm{IVP}\right)\right]$, respectively (Scheme 2$)$.

All these porphyrin derivatives have been characterized by UV-visible, fluorescence, IR and ${ }^{1} \mathrm{H}$ NMR spectrometry, as well as by mass spectrometry and cyclic voltammetry. The second part of this paper concerns the study of the chloride and bromide ions receptor by the zinc(II) chloro-triazole and iodinetriazole porphyrin complexes $\mathbf{5 b}$-c. The other important goal of the present work is to study the efficiency of the free base porphyrins $\mathbf{4 a - c}$ and the corresponding zinc(II) complexes $\mathbf{5 a - c}$ in the adsorption of the malachite green (MG) dye. The catalytic oxidative degradation efficiency of the MG dye using the three triazole meso-arylporphyrin zinc(II) compounds 5a-c have also

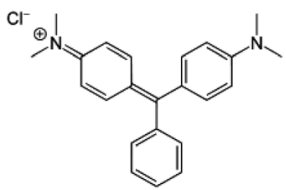

Scheme 1 Structure of the malachite green (MG) dye.

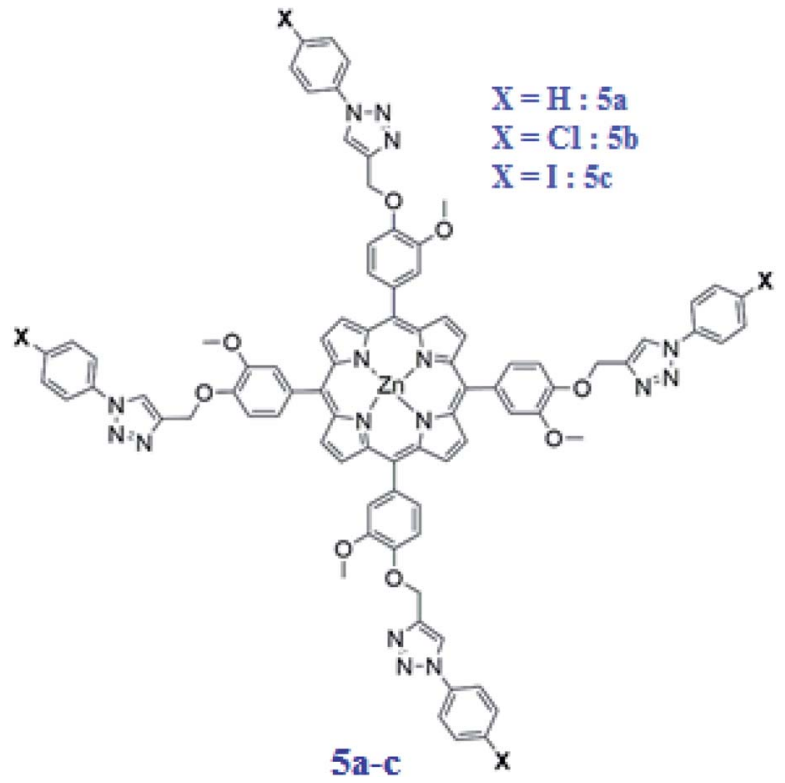

Scheme 2 Structure of $\left[\mathrm{Zn}\left(\mathrm{T}_{\mathrm{AzP}}-\mathrm{XVP}\right)\right]$ complexes. $5 \mathrm{a}: \mathrm{X}=\mathrm{H}, 5 \mathrm{~b}: \mathrm{X}=$ $\mathrm{Cl}$ and $5 \mathrm{c}: \mathrm{X}=\mathrm{I}$.

been described which is the first example of the use of a porphyrinic compound for the degradation of this dye.

\section{Results and discussion}

\subsection{Synthesis}

Scheme 3 depicts the overall synthetic route for the preparation of meso-tetrakis(3-methoxy-4-((1-phenyl-1H-1,2,3triazol-4-yl)methoxy)phenyl)porphyrin (4a) $\left[\mathrm{H}_{2}\left(\mathrm{~T}_{\mathrm{AzP}}-\mathrm{HVP}\right)\right]$, the meso-tetrakis(4-((1-(4-chlorophenyl)-1H-1,2,3-triazol-4yl)methoxy)-3-methoxyphenyl)porphyrin (4b) $\quad\left[\mathrm{H}_{2}\left(\mathrm{~T}_{\mathrm{AzP}^{-}}\right.\right.$ ClVP)] and the meso-tetrakis(4-((1-(4-iodinephenyl)-1H1,2,3-triazol-4-yl)methoxy)-3-methoxyphenyl)porphyrin (4c) $\left[\mathrm{H}_{2}\left(\mathrm{~T}_{\mathrm{AzP}}-\mathrm{IVP}\right)\right]$, as well as the corresponding zinc(II) metalloporphyrins $\mathbf{5 a}-\mathbf{c}$ with the formulas $\left[\mathrm{Zn}\left(\mathrm{T}_{\mathrm{AzP}}-\mathrm{HVP}\right)\right]$, $\left[\mathrm{Zn}\left(\mathrm{T}_{\mathrm{AzP}}-\mathrm{ClVP}\right)\right]$ and $\left[\mathrm{Zn}\left(\mathrm{T}_{\mathrm{AzP}}-\mathrm{IVP}\right)\right]$, respectively (see synthetic procedures in the ESI $\dagger$ ). The first step is the preparation of the 3-methoxy-4-(prop-2-ynl-yloxy) benzaldehyde (2). This derivative was prepared by reacting the 3-hydroxy-3-methoxy-benzaldehyde (1) with $\mathrm{K}_{2} \mathrm{CO}_{3}$ and the propargyl bromide in acetone under reflux for 4 hours. The second step is the synthesis of the three substituted [1,2,3](triazol-4-ylmethoxy)-benzaldehyde: 3-methoxy-4-(3phenyl-3H-[1,2,3]triazol-4-ylmethoxy)-benzaldehyde (3a), the 4-[3-(4-chloro-phenyl)-3H-[1,2,3]triazol-4-ylmethoxy]-3methoxy-benzaldehyde (3b) and the (4-iodine-phenyl)-3 $H^{-}$ $[1,2,3]$ triazol-4-ylmethoxy]-3-methoxy-benzaldehyde (3c). These compounds were prepared using the so-called "click reaction" (CuAAC) by reacting the 3-methoxy-4-(prop-2-ynlyloxy)benzaldehyde (2) with the 1-azidobenzene or the 1azido-4-chlorobenzene or the 1-azido-4-iodinebenzene and the diisopropylethylamine (DIPEA) reagents in the presence of copper(I) (CUI) catalyst. ${ }^{22}$ The success of the click reaction 
1
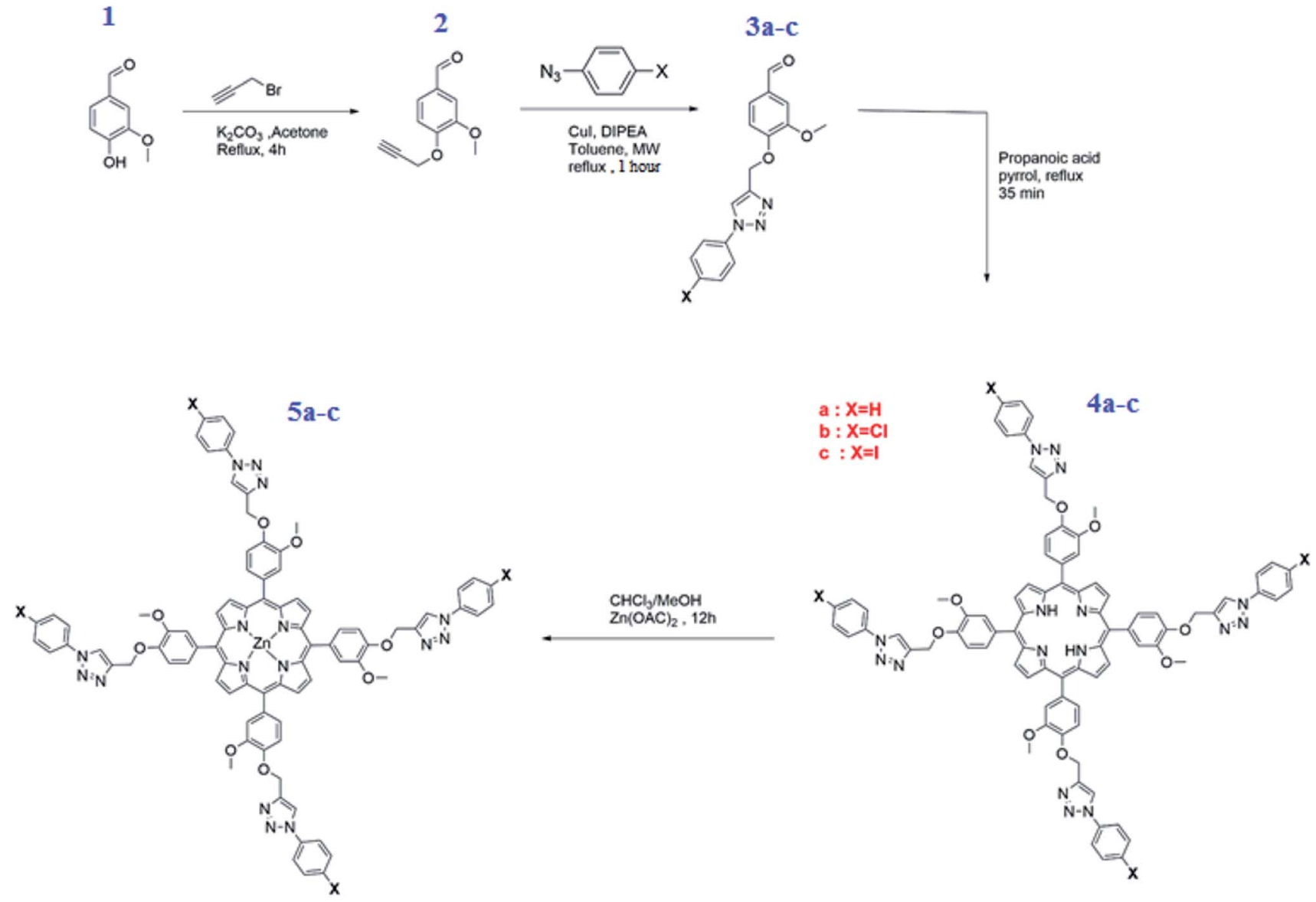

Scheme 3 Synthesis of aldehydes $2-3 a-c$, the free base porphyrins $4 a-c$ and the zinc(II) porphyrin complexes $5 a-c$.

is verified in IR by the disappearance of the two absorption bands of the azido group $\left(\nu_{\text {as }}\left(\mathrm{N}_{3}\right) \sim 2130\right.$ and $\left.\sim 2080 \mathrm{~cm}^{-1}\right)$ and the alkyne group of compound 2 and the appearance of a new band at $1726 \mathrm{~cm}^{-1}$ assigned to $\nu(\mathrm{C}=\mathrm{N}, \mathrm{N}=\mathrm{N})$ of the triazole group (Fig. SI- $2 \dagger$ ). The three triazole-meso-porphyrins 4a-c were prepared using a slightly modified AdlerLongo procedure. ${ }^{23}$ The metalation by the zinc(II) of the three $\mathbf{4 a - c}$ porphyrins were made according to the literature method $^{24}$ using the zinc(II) acetate salt $\mathrm{Zn}(\mathrm{OAc})_{2} \cdot 2 \mathrm{H}_{2} \mathrm{O}$ leading to the three zinc(II) metalloporphyrins $\left[\mathrm{Zn}\left(\mathrm{T}_{\mathrm{Az} \mathrm{P}^{-}}\right.\right.$ HVP)] (5a), [Zn( $\left.\left.\mathrm{T}_{\mathrm{AzP}}-\mathrm{ClVP}\right)\right](\mathbf{5 b})$ and $\left[\mathrm{Zn}\left(\mathrm{T}_{\mathrm{AzP}}-\mathrm{IVP}\right)\right](\mathbf{5 c})$. The three free base porphyrins $4 \mathbf{4 a - c}$ and the corresponding zinc(II) metalloporphyrins 5a-c were characterized by UVvisible, fluorescence, IR and ${ }^{1} \mathrm{H}$ NMR spectroscopies as well as by mass spectrometry.

\subsection{Mass spectrometry}

All synthetic compounds were characterized by ESI or MALDITOF mass spectrometry (see ESI $\dagger$ ). The MALDI-TOF spectra of our three zinc(II) metalloporphyrins $\left[\mathrm{Zn}\left(\mathrm{T}_{\mathrm{Az}} \mathrm{P}^{-} \mathrm{HVP}\right)\right],\left[\mathrm{Zn}\left(\mathrm{T}_{\mathrm{AzP}} \mathrm{P}^{-}\right.\right.$ $\mathrm{ClVP})]$ and $\left[\mathrm{Zn}\left(\mathrm{T}_{\mathrm{AzP}}-\mathrm{IVP}\right)\right](\mathbf{5 a}-\mathbf{c})$, shown in Fig. SI-1, $\dagger$ were recorded in the tetrahydrofuran solvent using the trans-2-[3-(4tert-butylphenyl)-2-propenylidene]malonitrile (DCTB) as matrix. For all three zinc(II) porphyrin species, the $[\mathrm{M}]^{+}$and $[\mathrm{M}+n \mathrm{H}]^{n+}$ fragments were observed which is a clear indication of the stability of the $\mathbf{5 a - c}$ compounds in THF solutions.

\subsection{IR and ${ }^{1} \mathrm{H}$ NMR investigation}

The IR spectra of the $4 a-c$ free base porphyrins and the corresponding zinc(II) metallated species 5a-c confirm the formation

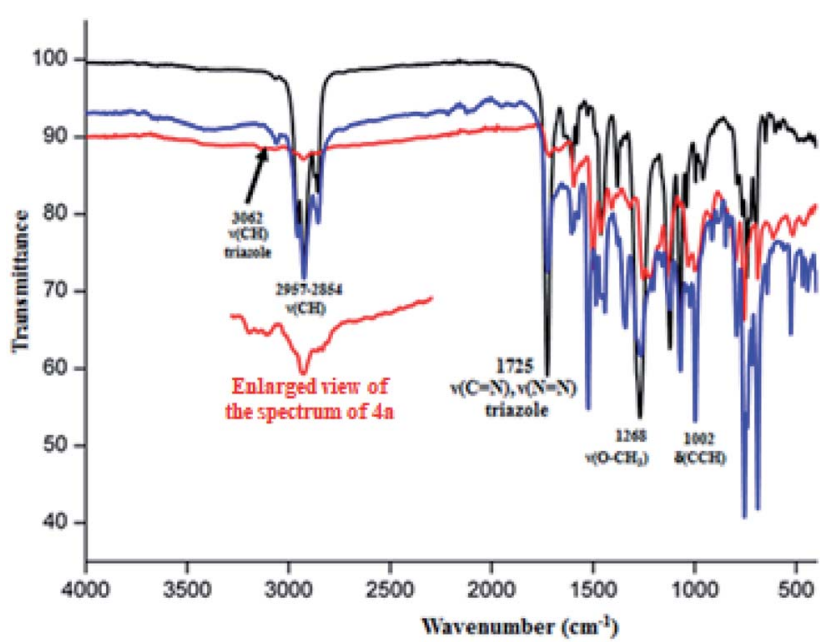

Fig. 1 IR spectra (solid state) of $\left[\mathrm{Zn}\left(\mathrm{T}_{\mathrm{AzP}}-\mathrm{HVP}\right)\right]$ (5a) (red color), [Zn( $\left.\left.T_{A z P}-C I V P\right)\right]$ (5b) (black color) and [Zn( $\left.\left.T_{A z P}-I V P\right)\right](5 c)$ (blue color). 
Table 1 UV-visible data of the three triazole meso-arylporphyrins (4a-c) and a selection of several meso-arylporphyrins and zinc(II) tetracoordinated metalloporphyrins. The solvent used is the dichloromethane

Free base meso-arylporphyrins

\begin{tabular}{|c|c|c|c|c|c|c|c|}
\hline \multirow[b]{2}{*}{ Compound } & \multicolumn{5}{|c|}{$\lambda_{\max }(\mathrm{nm})\left(\varepsilon \times 10^{-3} \mathrm{~L} \mathrm{mmol}^{-1} \mathrm{~cm}^{-1}\right)$} & \multirow[t]{2}{*}{$E_{\text {gap-opt }}(\mathrm{eV})$} & \multirow[t]{2}{*}{ Ref. } \\
\hline & Soret band & & & Q bands & & & \\
\hline $\mathrm{H}_{2}(\mathrm{TTP})^{b}$ & 420 & 516 & 552 & 594 & 640 & 1.86 & 27 \\
\hline $\mathrm{H}_{2}(\text { TPBP })^{c}$ & $420(513)$ & $516(17)$ & $552(7)$ & $591(5)$ & $646(4)$ & 1.82 & 4 \\
\hline $\mathrm{H}_{2}(\text { TEBOP })^{d}$ & $422(295)$ & $517(9)$ & $554(8)$ & $593(5)$ & $651(7)$ & 1.85 & 18 \\
\hline $\mathrm{H}_{2}\left(\mathrm{~T}_{\mathrm{AzP}}-\mathrm{IVP}\right) \mathbf{4 c}$ & $424(576)$ & $520(46)$ & $555(29)$ & $595(24)$ & $652(18)$ & 1.86 & This work \\
\hline
\end{tabular}

Zinc(ii) meso-arylporphyrin complexes

\begin{tabular}{|c|c|c|c|c|c|}
\hline Compound & \multicolumn{3}{|c|}{$\lambda_{\max }(\mathrm{nm})\left(\varepsilon \times 10^{-3} \mathrm{~L} \mathrm{mmol}^{-1} \mathrm{~cm}^{-1}\right)$} & $E_{\text {gap }}$-opt $(\mathrm{eV})$ & Ref. \\
\hline$[\mathrm{Zn}(\mathrm{TPP})]^{a}$ & $421(524)$ & $550(21)$ & $591(25)$ & 1.91 & 28 \\
\hline$[\mathrm{Zn}(\mathrm{TMP})]^{e}$ & 420 & 550 & 586 & - & 29 \\
\hline$[\mathrm{Zn}(\mathrm{TPBP})]^{c}$ & $425(546)$ & $554(24)$ & $596(9)$ & 1.99 & 24 \\
\hline$[\mathrm{Zn}(\mathrm{TEBOP})]^{d}$ & $424(219)$ & $552(11)$ & $594(5)$ & 2.03 & 18 \\
\hline
\end{tabular}

${ }^{a}$ TPP $=$ meso-tetraphenylporphyrinato. ${ }^{b}$ TTP $=$ meso-tetratolylporphyrinato. ${ }^{c}$ TPBP $=$ meso-tetrakis-[4-(benzoyloxy)phenyl $]$ porphyrinato. ${ }^{d}$ TEBOP $=$ meso-tetrakis(ethyl-4(4-butyryl)oxyphenyl)porphyrinato. ${ }^{e}$ TMP $=$ meso-tetrakis(2,4,6-trimethylphenyl)porphyrinato.

of the triazole meso-arylporphyrins as well as the corresponding zinc(II) coordination compound. Indeed, the values of the $\nu(\mathrm{CH})$ stretching frequencies of the $\mathrm{C}-\mathrm{H}$ bonds of the triazole and the aryl groups of $\mathrm{H}_{2}\left(\mathrm{~T}_{\mathrm{AzP}}-\mathrm{HVT}\right)$ (4a), $\mathrm{H}_{2}\left(\mathrm{~T}_{\mathrm{AzP}}-\mathrm{ClVT}\right)$ (4b) and $\mathrm{H}_{2}\left(\mathrm{~T}_{\mathrm{AzP}}\right.$-IVT) $(4 \mathrm{c})$ are $\sim 3070 \mathrm{~cm}^{-1}$ and in the [2955-2854] $\mathrm{cm}^{-1}$ range, respectively (Fig. SI-3†). For the zinc(II) corresponding complexes 5a-c (Fig. 1), the $\nu(\mathrm{CH})$ stretching frequencies values are practically the same as those of the free base porphyrins $\mathbf{4 a -}$ c. The presence of the triazole fragment is confirmed by a strong absorption band at $\sim 1725 \mathrm{~cm}^{-1}$ for both free base porphyrins 4a-c and the corresponding zinc(II) complexes 5a-c. This band is attributed to $\nu(\mathrm{N}=\mathrm{N})$ and $\nu(\mathrm{C}=\mathrm{N})$ of the triazole group. ${ }^{25}$ The metallation of $\mathbf{4 a - c}$ porphyrins are confirmed by (i) the disappearance of the absorption band correspondent to the $\nu\left(\mathrm{N}^{-}-\mathrm{H}\right)$ stretching frequency of the free base porphyrins $\left(\sim 3280 \mathrm{~cm}^{-1}\right)$ and (ii) by the shift of the deformation frequency $\delta(\mathrm{CCH})$ from $\sim 965 \mathrm{~cm}^{-1}$ (4a-c) to $\sim 1000 \mathrm{~cm}^{-1}$ for the zinc(II) complexes 5a-c (Fig. SI-3† and 1).

The proton NMR spectra of the three zinc(II) complexes 5a-c are shown in Fig. SI-4-6. $\dagger$ The $\beta$-pyrrolic protons of the three porphyrinates in complexes $\mathbf{5 a}-\mathbf{c}$ resonate at about $9 \mathrm{ppm}$ while the phenylic protons resonate between 7.19 and $7.71 \mathrm{ppm}$. For these three 5a-c species, the chemical shift values of the triazole protons are $\sim 8 \mathrm{ppm}$ and those of the $\mathrm{O}-\mathrm{CH}_{2}$-triazole groups are $\sim 5.4 \mathrm{ppm}$. The methoxy groups for $\mathbf{5 a - c}$ presents singlets at about $4.0 \mathrm{ppm}$.

\subsection{Photophysical properties}

The electronic absorption spectra of the free base porphyrins 4a-c and the corresponding zinc(II) metallated porphyrin species (5a-c) are depicted in Fig. SI-7 and SI-8 $\dagger$ while the UVvisible data are given in Table 1. The $\lambda_{\max }$ values of the Soret band of the free base porphyrins $4 \mathrm{a}-\mathrm{c}$ are $\sim 420 \mathrm{~nm}$ while those

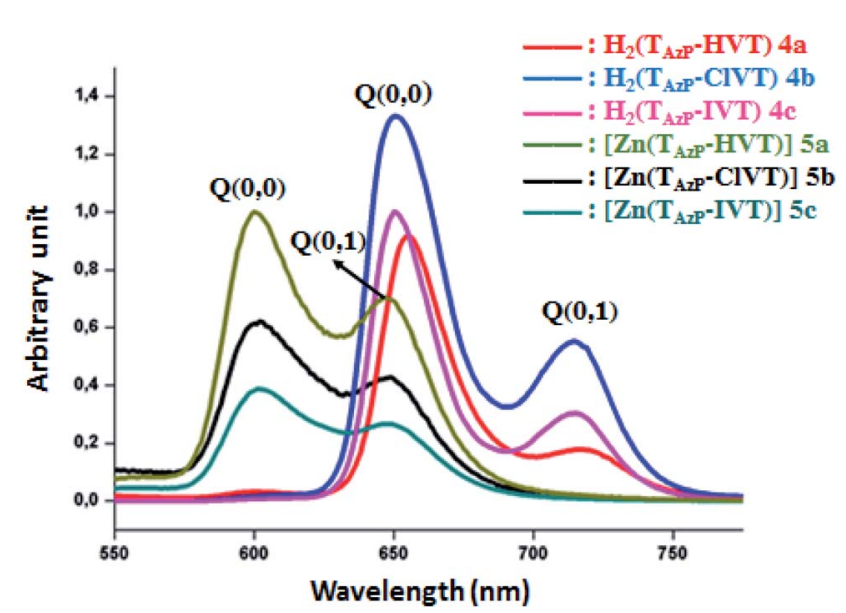

Fig. 2 The emission spectra of compounds $4 a-c$ and $5 a-c$. The spectra were recorded in dichloromethane solvent with a concentration $\sim 10^{-6} \mathrm{M}$. The excitation wavelength value is $430 \mathrm{~nm}$. 
Table 2 Emission parameter values of several meso-arylporphyrins and a selection of zinc(II) meso-metalloporphyrins

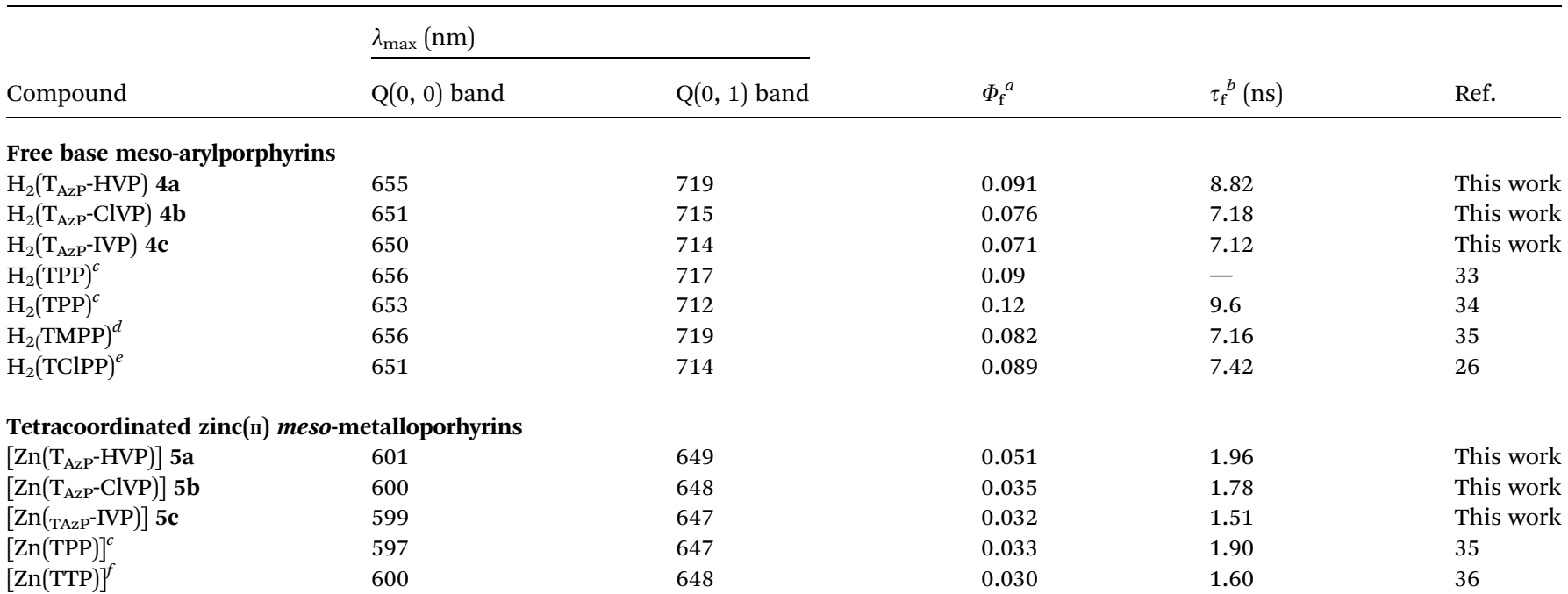

${ }^{a} \Phi_{\mathrm{f}}=$ fluorescence quantum yield. ${ }^{b} \tau_{\mathrm{f}}=$ fluorescent lifetime. ${ }^{c} \mathrm{H}_{2}(\mathrm{TPP})=$ meso-tetraphenylporphyrin. ${ }^{d} \mathrm{H}_{2}(\mathrm{TMPP})=$ meso-tetra(para-methoxy) phenylporphyrin. ${ }^{e} \mathrm{H}_{2}$ (TClPP) $=$ meso-tetra(para-chlorophenyl)porphyrin. ${ }^{f}$ TTP $=$ meso-tetratolylporphyrinato.

of the $\mathrm{Q}$ bands are $\sim 518, \sim 550, \sim 590$ and $\sim 650 \mathrm{~nm}$ which are typical for meso-arylporphyrins. For the tetracoordinated zinc(II) coordination compounds 5a-c type $[\mathrm{Zn}(\mathrm{Porph})]$ (Porph $=\mathrm{T}_{\mathrm{AzP}^{-}}$ $\mathrm{HVP}$ or $\mathrm{T}_{\mathrm{AzP}}$-ClVP or $\mathrm{T}_{\mathrm{AzP}}-\mathrm{IVP}$ porphyrinates), the Soret and the $\mathrm{Q}$ bands of these metalloporphyrins are, as expected, slightly redshifted compared to the corresponding free base porphyrins.

Notably, the UV-visible data of our three free bases and the corresponding zinc metallated porphyrins are very close to those of the reported zinc(II) related species (Table 1). The optical gap values ( $E_{\mathrm{g}}$-op) of our synthetic compounds $\mathbf{4 a - c}$ and $\mathbf{5 a}-\mathbf{c}$ were determined using the Tauc's relation (eqn (1)): ${ }^{\mathbf{3 0 , 3 1}}$

$$
(\alpha h \nu)^{2}=A\left[h \nu-E_{\mathrm{g}}-\mathrm{op}\right]
$$

where $A$ is a constant parameter depending on transition probability, $h \nu$ is the incident photon energy and $\alpha$ is the optical absorption coefficient deduced from absorbance data. The intercepts between the solid lines and $x$-axis allow the determination of $E_{\mathrm{g}}$-op values (Fig. SI-9†). The optical gap energy values of the free bases $\mathbf{4 a - c}$ are $1.88,1.87$ and $1.86 \mathrm{eV}$, respectively, while those of the corresponding zinc(II) complexes 5a-c are 2.05, 2.02 and $2.01 \mathrm{eV}$, respectively. The fact that the $E_{\mathrm{g}}$ op values of the metallated porphyrins are higher than those of the free bases is mainly due to the higher flexibility of the non metallated porphyrins which leads to the destabilization of the HOMO-LUMO orbital energies. Thus, the net result is the reduction of the gap energy values of these meso-porphyrins. However, the zinc metallation of these tetradentate ligands decreases the distortion of the porphyrin core. Therefore, the values of the optical energy of the metalloporphyrins are usually higher than those of the non metallated porphyrins. ${ }^{32}$ We notice that both 4a-c porphyrins and 5a-c Zn(II) metalloporphyrins present $E_{\mathrm{g}}$-op values very close to the related meso-arylporphyrins and zinc(II) meso-arylporphyrins. Fig. 2 illustrates the fluorescence spectra of $\mathbf{4 a - c}$ and $\mathbf{5 a}-\mathbf{c}$, while the photoluminescence data of these porphyrin species are given in Table 2.

Importantly, it should be noticed that porphyrin derivatives exhibit interesting photophysical properties especially due to the significant aromaticity of the porphyrin macrocycle. Indeed, these species present one very weak emission transition $S_{2} \rightarrow S_{0}$ of the Soret band between the second excited singlet state $\mathrm{S}_{2}$ and the ground state $S_{0}$. The second emission transition of porphyrin and metalloporphyrins, which is much stronger than the first transition, is the $S_{1} \rightarrow S_{0}$ of the $Q$ bands between the first excited singlet state $S_{1}$ to the ground state $S_{0}$. Therefore, only the following two $S_{1} \rightarrow S_{0}$ transitions are observed for the

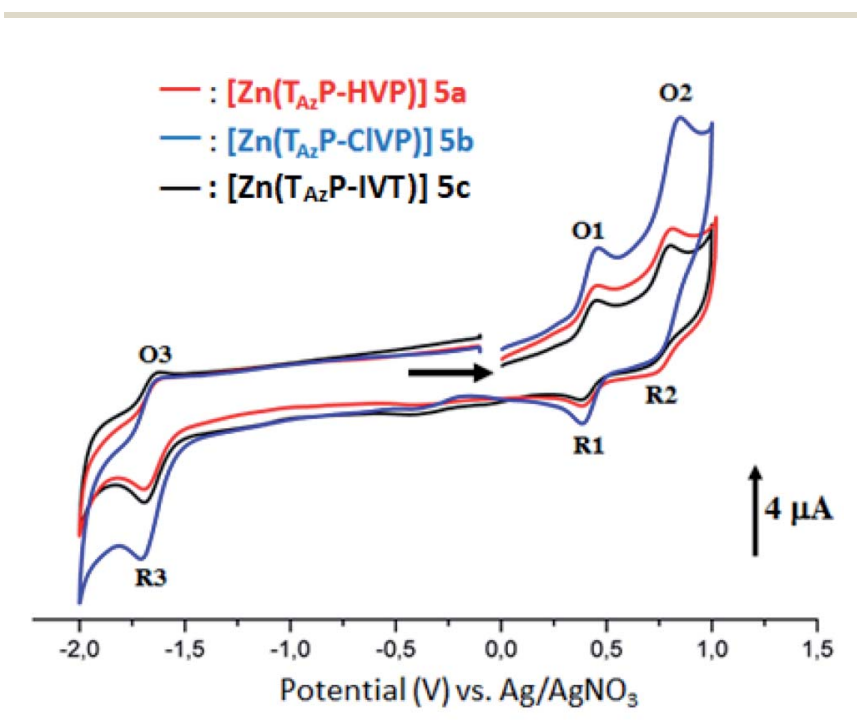

Fig. 3 Cyclic voltammograms of complexes $5 \mathrm{a}-\mathrm{c}$. The solvent is a mixture of dichloromethane and acetonitrile (4/1) and the concentration is ca. $10^{-3} \mathrm{M}$ in $0.1 \mathrm{M} \mathrm{TBAPF}_{6}, 100 \mathrm{mV} \mathrm{s}^{-1}$, vitreous carbon working electrode $(\varnothing=2 \mathrm{~mm})$. 
Table 3 Electrochemical data ${ }^{a}$ for the three free base triazole meso-arylporphyrins $4 a-c$ and the corresponding zinc(॥) complexes $5 a-c$ and a selection of several related porphyrins species

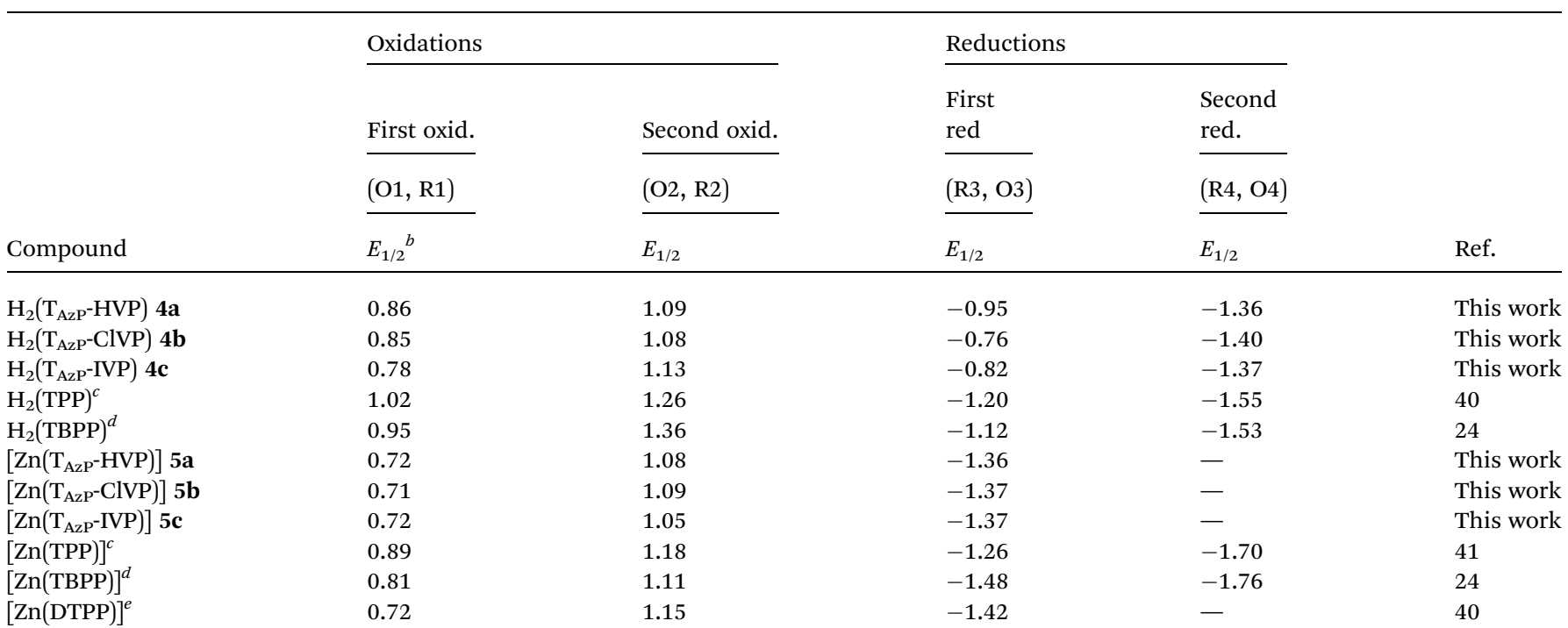

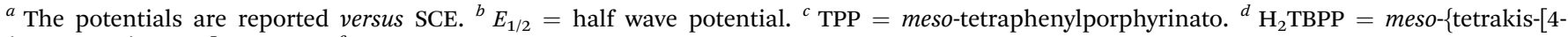
(benzoyloxy)phenyl]porphyrin. ${ }^{e}$ DTPP $=5,15$ - $p$-ditolyl-10-phenylporphyrinato.

free base porphyrins and metalloporphyrin complexes: $\mathrm{S}_{1}[\mathrm{Q}(0$, $0)] \rightarrow S_{0}$ and $S_{1}[Q(0,1)] \rightarrow S_{0}$. For the three free base porphyrin species $4 \mathbf{a}-\mathbf{c}$, the emission spectra show two bands: the weak band at $\lambda_{\max } \sim 715 \mathrm{~nm}$ is assigned as $\mathrm{Q}(0,1)$, and the stronger band at $\lambda_{\max } \sim 650 \mathrm{~nm}$ is assigned as $\mathrm{Q}(0,0)$ (Fig. 2). The values of each $\lambda_{\max }$ of our three derivatives are very close to those of the reported meso-arylporphyrins (Table 2). The hypochromic shifts of the $\mathrm{Q}(0,0)$ and the $\mathrm{Q}(0,1)$ of the zinc(II) metalloporphyrins $\mathbf{5 a}-\mathbf{c}$ compared to those of the corresponding free bases $\mathbf{4 a - c}$ are important for consideration. The $\lambda_{\max }$ values of the $\mathrm{Q}(0,0)$ band are $\sim 600 \mathrm{~nm}$, while the $\lambda_{\max }$ values of the $\mathrm{Q}(0,1)$ bands are $\sim 650 \mathrm{~nm}$. These shifts are mainly due to the metallation of the porphyrins..$^{37}$ The Stocks shifts values of the free bases $\mathbf{4 a - c}$ and the 5a-c zinc(II) metalloporphyrins are small, indicating a fluorescence emission with no significant conformational change between the fundamental and excited states.

The fluorescence properties were studied by both steadystate and time-resolved fluorescence techniques. As indicated in Table 2, the fluorescence quantum yield $\left(\Phi_{\mathrm{f}}\right)$ value of the $\mathrm{H}_{2} \mathrm{~T}_{\mathrm{AzP}}-\mathrm{HVP}$ (4a) is slightly higher than those of the chloro-triazole and iodine-triazole free base derivatives $\mathrm{H}_{2} \mathrm{~T}_{\mathrm{AzP}}$-ClVP (4b) and $\mathrm{H}_{2} \mathrm{~T}_{\mathrm{AzP}}$-IVP (4c) with $\Phi_{\mathrm{f}}$ values of $9.1 \%, 7.6 \%$ and $7.1 \%$, respectively, which could be attributed to the higher molar mass of the iodine (in $\mathbf{4 c}$ ) and chlorine (in $\mathbf{4 b}$ ) atoms compared to that of the hydrogen atom (in $\mathbf{4 a}$ ). Notably, the $\Phi_{\mathrm{f}}$ value of the $\mathbf{4 a}$ porphyrin is comparable with that of the meso-tetraphenylporphyrin $\mathrm{H}_{2}$ TPP $\left(\Phi_{\mathrm{f}} \sim 10\right)$ (Table 2$)$. As expected the $\Phi_{\mathrm{f}}$ values of our three zinc(II) porphyrins 5a-c which are $5.1 \%, 3.5$ and $3.1 \%$, respectively, are quite smaller than those of the related free base porphyrins $4 \mathbf{4 a - c}$. We also notice that the iodine-triazole and chloro-triazole zinc(II) derivatives exhibit slightly higher fluorescence quantum yields than that of the H-triazole porphyrin species. The lifetime of singlet excited state $\left(\tau_{\mathrm{f}}\right)$ was measured by the single photon counting technique, and the fluorescence decays were fitted to single exponentials. The representative fluorescence decays $\left(\tau_{\mathrm{f}}\right)$ of these four derivatives are similar (see Fig. SI-10†). Our [Zn(Porph)] complexes (5a-c) display, as expected, $\tau_{\mathrm{f}}$ values between 7.2 and $8.82 \mathrm{~ns}$ which are much higher than the corresponding free bases $(\mathbf{4 a - c})$ with values in the range 1.51 and $1.96 \mathrm{~ns}$.

\subsection{Cyclic voltammetry}

Cyclic voltammograms (CV) of our porphyrin derivatives 4a-c and $\mathbf{5 a}-\mathbf{c}$ were recorded at room temperature in a mixture of dichloromethane and acetonitrile (4/1) under an argon atmosphere with tetrabutylammonium hexafluorophosphate $\left(\mathrm{TBAPF}_{6}\right)$ as the supporting electrolyte $(0.1 \mathrm{M})$. The $\mathrm{CV}$ of the free base porphyrins $\mathbf{4 a - c}$ are illustrated in Fig. SI-11, $\dagger$ while those of the corresponding zinc(II) complexes 5a-c are depicted in Fig. 3. The electrochemical data of our synthetic porphyrin species and several related compounds are given in Table 3 . The free bases $\mathbf{4 a - c}$ exhibit two reversible one-electron reduction waves and two reversible one-electron oxidation waves, which correspond to the reduction and the oxidation of the porphyrin ring. The half potential values $\left(E_{1 / 2}\right)$ of the three triazole mesoarylporphyrins $\mathbf{4 a - c}$ are much smaller than those of the unsubstituted meso-tetraphenylporphyrin $\left(\mathrm{H}_{2} \mathrm{TPP}\right)$ (Table 3). Neya et al., ${ }^{38}$ reported that the second reduction of the porphyrin ring in metalloporphyrins, with non-redox-active cationic metal centers such as $\mathrm{Zn}$ (II) and $\mathrm{Mg}$ (II), is usually not observed in the electrochemical window of the solvent which is the case for our zinc(II) derivatives 5a-c. It was also reported that the zinc metallation of the meso-arylporphyrins leads to the shifts of the characteristic reduction and oxidation potentials to more negative values. ${ }^{29,39}$ In our case, only the $E_{1 / 2}$ values of the 
first reduction waves for $\left[\mathrm{Zn}\left(\mathrm{T}_{\mathrm{azP}}-\mathrm{HVP}\right)\right],\left[\mathrm{Zn}\left(\mathrm{T}_{\mathrm{azP}}-\mathrm{ClVP}\right)\right]$ and $\left[\mathrm{Zn}\left(\mathrm{T}_{\mathrm{azP}}-\mathrm{IVP}\right)\right](\mathbf{5 a}-\mathbf{c})$ are shifted to more negative values (Table 3).

In short, the CV investigation on our synthetic $4 \mathbf{4 a}-\mathbf{c}$ and $\mathbf{5 a - c}$ porphyrin species show that the nature of the substituted groups on the phenyls of the meso-arylporphyrins do not have a very significant effect on the electrochemical properties of this type of species.

Ghosh et al.,$^{\mathbf{4 2}}$ estimated the electrochemical gap energy $\left(E_{\mathrm{g}^{-}}\right.$ el) as the difference between the potential of the first oxidation potential and the first reduction potential of the porphyrin. The estimated energy values of the HOMO and LUMO orbitals as well as the value of the $E_{\mathrm{g}}$-el can be calculated using the following equations (eqn (2)-(4)): ${ }^{43}$

$$
\begin{gathered}
E_{\mathrm{HOMO}}=-\left(V_{\text {onset-ox }}-V_{\text {ref }}+4.8\right) \mathrm{eV} \\
E_{\mathrm{LUMO}}=-\left(V_{\text {onset-red }}-V_{\text {ref }}+4.8\right) \mathrm{eV} \\
E_{\mathrm{g}} \text {-el }=\left(E_{\text {LUMO }}-E_{\mathrm{HOMO}}\right) \mathrm{eV}
\end{gathered}
$$

The $E_{\mathrm{HOMO}}$ and the $E_{\mathrm{LUMO}}$ are also known as the ionization potential (IP) and the electron affinity (EA), respectively. The $V_{\text {onset-ox }}$ and the $V_{\text {onset-red }}$ are the oxidation onset and the reduction onset, respectively and the $V_{\text {ref }}$ is the reference halfwave potential. The values of $E_{\mathrm{HOMO}}, E_{\mathrm{LUMO}}$ and $E_{\mathrm{g}}$-el were calculated using equations eqn (2)-(4) and are reported in Table 4 along with those of several related compounds. The energy level of the HOMO and LUMO orbitals as well as the $E_{\mathrm{g}}$-el of $4 \mathbf{4 a - c}$ and 5a-c are illustrated in Fig. SI-12. $\dagger$ From Table 4 we can deduce: (i) except for the case of the $\mathrm{H}_{2}$ (TPBP) porphyrin, the electrochemical gap energy values of the zinc metalloporphyrins are higher than those of the free base porphyrins; (ii) as expected, the values of the $E_{\mathrm{g}}$-el of $\mathbf{4 a - c}$ and $5 \mathbf{a}-\mathbf{c}$ are higher than those of the $E_{\mathrm{g}}$-op (optical gap energy) of the same species, which is also the case for all known meso-

Table 4 Values of the HOMO, LUMO orbitales energies and the electrochemical gap energy for a selection of porphyrins species

\begin{tabular}{lccll}
\hline Compound & $E_{\text {HOMO }}(\mathrm{eV})$ & $E_{\text {LUMO }}(\mathrm{eV})$ & $\begin{array}{l}E_{\mathrm{g}} \text {-el } \\
(\mathrm{eV})\end{array}$ & Ref. \\
\hline \multicolumn{5}{c}{ Free base meso-arylporphyrins } \\
$\mathrm{H}_{2}(\mathrm{TPP})^{a}$ & -5.50 & -3.49 & 2.01 & 44 \\
$\mathrm{H}_{2}(\mathrm{TPBP})^{b}$ & -5.87 & -3.73 & 2.14 & 24 \\
$\mathrm{H}_{2}\left(\mathrm{~T}_{\mathrm{AzP}}-\mathrm{HVP}\right)$ 4a & -5.40 & -3.45 & 1.95 & This work \\
$\mathrm{H}_{2}\left(\mathrm{~T}_{\mathrm{AzP}}-\mathrm{ClVP}\right)$ 4b & -5.53 & -3.66 & 1.87 & This work \\
$\mathrm{H}_{2}\left(\mathrm{~T}_{\mathrm{AzP}}-\mathrm{IVP}\right)$ 4c & -5.32 & -3.56 & 1.77 & This work \\
& & & & \\
$\mathrm{Zinc}(\mathrm{II})$ meso-arylporphyrin tetracoordinated complexes & \\
{$[\mathrm{Zn}(\mathrm{TPP})]^{a}$} & -5.58 & -3.46 & 2.12 & 45 \\
{$[\mathrm{Zn}(\mathrm{TPBP})]^{b}$} & -5.64 & -3.27 & 2.37 & 24 \\
{$\left[\mathrm{Zn}\left(\mathrm{T}_{\mathrm{AzP}}-\mathrm{HVP}\right)\right]$ 5a } & -5.24 & -3.09 & 2.15 & This work \\
{$\left[\mathrm{Zn}\left(\mathrm{T}_{\mathrm{AzP}}-\mathrm{ClVP}\right)\right]$ 5b } & -5.23 & -3.09 & 2.14 & This work \\
{$\left[\mathrm{Zn}\left(\mathrm{T}_{\mathrm{AzP}}-\mathrm{IVP}\right)\right]$ 5c } & -5.24 & -3.11 & 2.13 & This work
\end{tabular}

${ }^{a}$ TPP $=$ meso-tetraphenylporphyrinato. ${ }^{b}$ TBPP $=$ meso-tetrakis-[4(benzoyloxy)phenyl]porphyrinato. arylporphyrins and the corresponding [Zn(Porph)] complexes $^{24}$ and (iii) the iodine-triazole fee base porphyrin 4c exhibits the smallest $E_{\mathrm{g}}$-el gap value $(1.77 \mathrm{eV})$ compared to those of $\mathbf{4 a}-$ b (1.95 and $1.87 \mathrm{eV}$, respectively) while the three zinc(II) metallated porphyrins $5 \mathbf{a}-\mathbf{c}$ presents very close values of $E_{\mathrm{g}}$-el $\sim$ $2.14 \mathrm{eV}$.

\subsection{Anion binding studies}

The zinc(II) complexes $\mathbf{5 b}$-c with the chloro-triazole and the iodine-triazole meso-porphyrinates were tested as $\mathrm{Cl}^{-}$and $\mathrm{Br}^{-}$ anions detector by UV-visible titration. The two halide ions titrations, carried out in dichloromethane solvent, revealed significant perturbation of the Soret and the $\mathrm{Q}$ bands of the zinc(II) 5b-c receptors as a function of the concentration of the tert-butyl ammonium chloride and bromide salts (TBACl and $\mathrm{TBABr}$ ). In the literature, several UV-visible titrations involving the tetracoordinated zinc(II) meso-porphyrins type [Zn(Porph)] (Porph $=$ meso-arylporphyrin) and neutral $\mathrm{N}$-donor ligands are reported. ${ }^{18}$ These investigations indicate the presence of a redshift of the Soret and the $\mathrm{Q}$ bands, upon addition of the axial ligand, of about $10 \mathrm{~nm}$ and $5 \mathrm{~nm}$ for the two bands, respectively, and the formation of a $1: 1$ coordination complex type $[\mathrm{Zn}($ Porph)(L)] ( $\mathrm{L}=\mathrm{N}$-neutral axial ligand).

The UV-visible titration spectra of $\left[\mathrm{Zn}\left(\mathrm{T}_{\mathrm{AzP}}-\mathrm{ClVP}\right)\right](\mathbf{5 b})$ (concentration about $10^{-6} \mathrm{M}$ ) with $\mathrm{Cl}^{-}$, in the Soret region, are shown in Fig. 4 and 5. The gradual addition of chloride to $\mathbf{5 b}$ leads to a bathochromic shift of the Soret band from $426 \mathrm{~nm}$ to $436 \mathrm{~nm}\left(\Delta \lambda_{\max }=10 \mathrm{~nm}\right)$ with one distinct isosbestic point at $431 \mathrm{~nm}$. In the $\mathrm{Q}$ region, the titration of the same complex $\mathbf{5 b}$ with $\mathrm{Cl}^{-}$exhibits also a redshift of the $\mathrm{Q}(0,0)$ and $\mathrm{Q}(0,1)$ bands. The titration of the same complex $\mathbf{5 b}$ with the bromide anion, using the same solvent and concentration as the $\mathrm{Cl}^{-}$titration, gives a comparable result with a redshift of the Soret and the Q bands (Fig. 4). The isosbestic points are $431 \mathrm{~nm}$ for the Soret

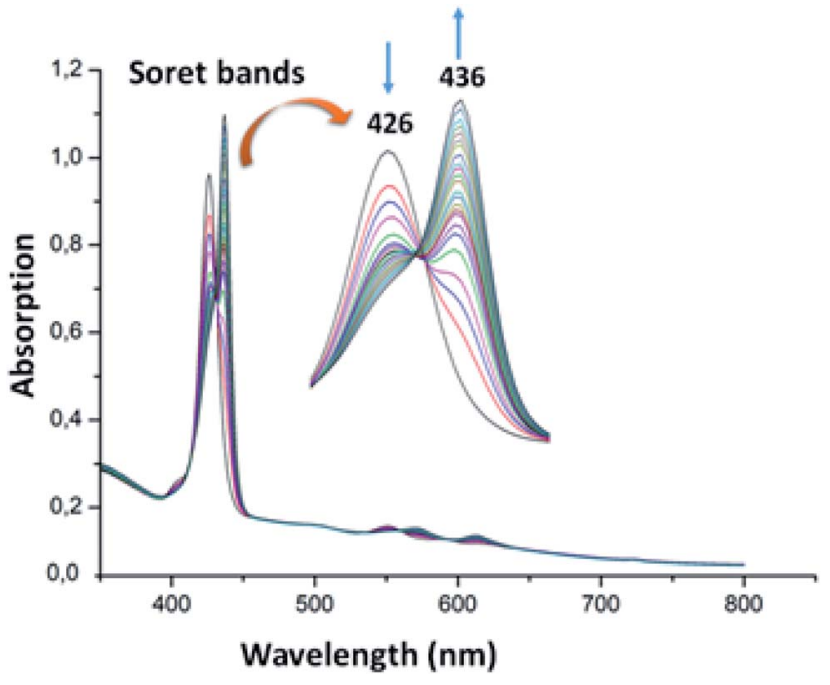

Fig. 4 Changes in the absorption spectra in the Soret band region of complex $5 \mathrm{~b}\left(\sim 10^{-6} \mathrm{M}\right)$ recorded in dichloromethane, upon addition of $\mathrm{Cl}^{-}(0-500$ equiv.). The inset shows enlarged view. 
region and 561 and $594 \mathrm{~nm}$ for the $\mathrm{Q}$ bands region. These values are practically the same as those of the $\mathrm{Cl}^{-}$titration.

For the zinc iodine-triazole complex $\left[\mathrm{Zn}\left(\mathrm{T}_{\mathrm{AzP}}-\mathrm{IVP}\right)\right](\mathbf{5 c})$, the titrations with both the $\mathrm{Cl}^{-}$and $\mathrm{Br}^{-}$halide ions are very similar to each other and to those of the zinc chloro-triazole complex 5b (Fig. 6 and 7). As mentioned above, the presence of isosbestic points is an indication of formation of a $1: 1$ receptor/anion adduct, i.e., leading to a pentacoordinate complex type $[\mathrm{Zn}(\mathrm{Porph})(\mathrm{L})]$. The redshift of the absorption bands of metalloporphyrins is due to the narrowing of the HOMO-LUMO and the energy gap is explained by the deformation of the porphyrin core. ${ }^{46}$ This bathochromic effect is also related to the electronwithdrawing groups at the meso and $\beta$-pyrrolic positions of the porphyrin macrocycle and to the nature of the metal ion. ${ }^{\mathbf{4 7 , 4 8}}$

In order to compare the $\mathrm{Cl}^{-}$and $\mathrm{Br}^{-}$detecting properties of our zinc complexes 5a-b with those of the unsubstituted zinc(II)meso-tetraphenylporphyrin ([Zn(TPP)]) we also performed a UVvisible titration in the Soret band region of this complex with $\mathrm{Cl}^{-}$and $\mathrm{Br}^{-}$halide ions. The spectra concerning these titrations are shown in Fig. SI-13. $\dagger$ The association constants values of the $1: 1$ complexes $\mathbf{5 a}-\mathbf{b}: \mathrm{X}\left(\mathrm{X}=\mathrm{Cl}^{-}\right.$and $\left.\mathrm{Br}^{-}\right)$as well as those of the $[\mathrm{Zn}(\mathrm{TPP}) \mathrm{X}]$ compounds are reported in Table SI-1. $\dagger$ To calculate these associate constants $K_{\text {as }}$ (and $\log K_{\text {as }}$ ) we use the so-called "strong interactions" method ${ }^{49}$ (see the ESI $\dagger$ for details).

A close inspection of Table SI-1† indicates that the iodinetriazole zinc derivative $\mathbf{5 c}$ presents a better binding affinity than the chloro-triazole zinc metalloporphyrin $\mathbf{5 b}$ for both $\mathrm{Cl}^{-}$and $\mathrm{Br}^{-}$anions. This could be explained by the higher donor effect of the chlorine in the para position of the $\mathrm{T}_{\mathrm{AzP}}-\mathrm{ClVP}$ porphyrinate than that of the iodine atom in the $\mathrm{T}_{\mathrm{Az}} \mathrm{P}^{-I V P}$ moiety leading to a higher electron density on the zinc(II) center metal for $\mathbf{5} \mathbf{b}$. Therefore, the bonding affinity of zinc(II) in $\mathbf{5 b}$ for the two halides is smaller than that of the iodine-triazole zinc $\mathrm{T}_{\mathrm{AzP}}-\mathrm{IVP}$ receptor. In contrast, the value of the $\log K_{\text {as }}$ for the $\mathbf{5 b}$ receptor for $\mathrm{Cl}^{-}$is higher than that for $\mathrm{Br}^{-}$which are 4.0245 and 3.5512, respectively. This is not the case for the $\mathbf{5 c}$ receptor for which $\log K_{\text {as }}$ value, in the case of the $\mathrm{Br}^{-}$anion, is higher than that for the $\mathrm{Cl}^{-}$anion; i.e. $\log K_{\mathrm{as}}$ is 4.6179 and 5.0566, respectively.

Notably, our two receptors present much better affinity for $\mathrm{Cl}^{-}$and $\mathrm{Br}^{-}$than the zinc(II) unsubstituted meso-tetraphenylporphyrin complex ([Zn(TPP)]) used as reference (Table SI- $1 \dagger$ ).

Beer et al.,12 reported the use of a zinc(II) cage porphyrin complex $[\mathrm{Zn}(\mathrm{PC})] \quad(\mathrm{PC}=$ meso-tetrayltetrakis(carbonyloxymethanediyl-1 $H$-1,2,3-triazole-4,1-diylmethanediyl)tetraphenyl)porphyrin) as receptor of several anions (such as $\mathrm{F}^{-}, \mathrm{Cl}^{-}, \mathrm{Br}^{-}, \mathrm{I}^{-}$ and $\mathrm{SO}_{4}{ }^{2-}$ ). This later complex presents a high binding affinity for $\mathrm{Cl}^{-}\left(\log K_{\mathrm{as}}=4.0860\right)$, but a very small association constant $K_{\text {as }}$ value $(<50)$ for $\mathrm{Br}^{-}$. This can be explained by the small size of the porphyrin cage which is not accommodated to host the highly diffuse bromine ion. It is interesting to note (i) that our zinc(II) chlorine porphyrin derivative (5b) has a similar bonding affinity for $\mathrm{Cl}^{-}$ion as the $[\mathrm{Zn}(\mathrm{PC})]$ related receptor with very close log $K_{\text {as }}$ values (4.0224 and 4.0860, respectively) and (ii) our iodine-triazole zinc derivative (5c) exhibits much better bonding affinity for $\mathrm{Cl}^{-}$anion than the zinc-porphyrin cage species ([Zn(PC)] with $\log K_{\text {as }}$ value of 4.6179 for our $5 \mathbf{c}$ complex compared to $\log K_{\text {as }}$ value of 4.0860 [ $\left.\mathrm{Zn}(\mathrm{PC})\right]$.

\subsection{Adsorption}

The adsorption process is generally due to several physicochemical forces that occur at the solid-liquid interface such as van der Waals forces, ${ }^{\mathbf{5 0}, 51}$ hydrogen bonds ${ }^{\mathbf{5 2}}$ and hydrophobic interactions. ${ }^{53,54}$ To determine the efficiency of adsorption of the MG dye on the $\mathbf{4 a - c}$ free base porphyrins and the corresponding zinc(II) complexes 5a-c, we carried out a kinetic study using our synthetic porphyrin derivatives as adsorbents. The adsorption spectrum of MG dye as a function of time in presence of $4 \mathbf{4}-\mathbf{c}$ and 5a-c species are shown in Fig. SI-14. $\dagger$ The adsorption efficiency $(R \%)$ of the $\mathrm{MG}$ dye on $\mathbf{4 a}-\mathbf{c}$ and $5 \mathbf{a}-\mathbf{c}$ porphyrin compounds are depicted in Fig. 8. The $R \%$ values for the $\mathbf{4 a - c}$ free base porphyrins are $35.5,37.25$ and $36.5 \%$, while those for the 5a-c complexes are $29,31.75$ and $30.75 \%$, respectively. The fact that the adsorption efficiency of the free base porphyrins are higher than those of the corresponding [ $\mathrm{Zn}$ (Porph)] complexes 5a-c could be related to the pyrrole hydrogen atoms in 4a-c leading to hydrogen bond type interactions with the nitrogens of the MG dye molecules. Notably, the chloro-triazole and iodine-triazole $\mathbf{4 b}$-c free base meso-arylporphyrin derivatives present better adsorption than that of the $\mathrm{H}$-triazole $\mathrm{T}_{\mathrm{AzP}^{-}}$ HVP species (4a). This trend is also present in the corresponding zinc(II) porphyrin complexes (5a-c). This might result from the fact that the chlorine and iodine atoms in the case of the $\mathbf{4 b}$ c and $5 \mathbf{b}-\mathbf{c}$ species are involved in a $n-\pi$ type interactions with the MG molecules, which is not possible in the case of the $\mathrm{H}^{-}$ triazole $\mathbf{4 a}$ and the chloro-triazole 5a porphyrin species (Fig. SI-15†). ${ }^{55}$ It should also be noticed that all $\mathbf{4 a - c}$ and $5 \mathbf{a}-\mathbf{c}$ porphyrin compounds present $\pi-\pi$ type interactions with the MG dye molecules (Fig. SI-16†). Furthermore, the nitrogen atom of the $-\left(\mathrm{CH}_{3}\right)_{2} \mathrm{~N}$ - group of the malachite green molecule is most likely coordinated to the center $\mathrm{Zn}^{2+}$ ion as in the case of $\mathrm{N}$ donor ligands (L) which react with the tetra-coordinated [Zn(Porph)] species leading to penta-coordinated complexes type $[\mathrm{Zn}(\mathrm{Porph})(\mathrm{L})]$.

\subsection{Adsorption kinetic}

Adsorption kinetic determines the time required to reach equilibrium between the solute and the adsorbent and it also gives an idea of the adsorption mechanism and the mode of transfer between the liquid and solid phases. Several kinetic models have been developed to describe the adsorption kinetics and to specify the nature of the interactions at the solid-liquid interface. In this work, four kinetic models have been selected to study the kinetic behavior of the MG dye at the surface of our porphyrinic compounds, namely: the pseudo first order kinetic model, the pseudo second order kinetic model, the intraparticle diffusion model and the Elovich model. ${ }^{56}$ The adsorption capacity curves as function of time for our six porphyrinic compounds (4a-c and 5a-c) are given in Fig. 9.

Fig. SI-17† illustrates the experimental data of the adsorption of MG dye on the $\mathbf{4 a - c}$ and $\mathbf{5 a - c}$ compounds. The data were fitted using the four kinetic models and the results are given in 


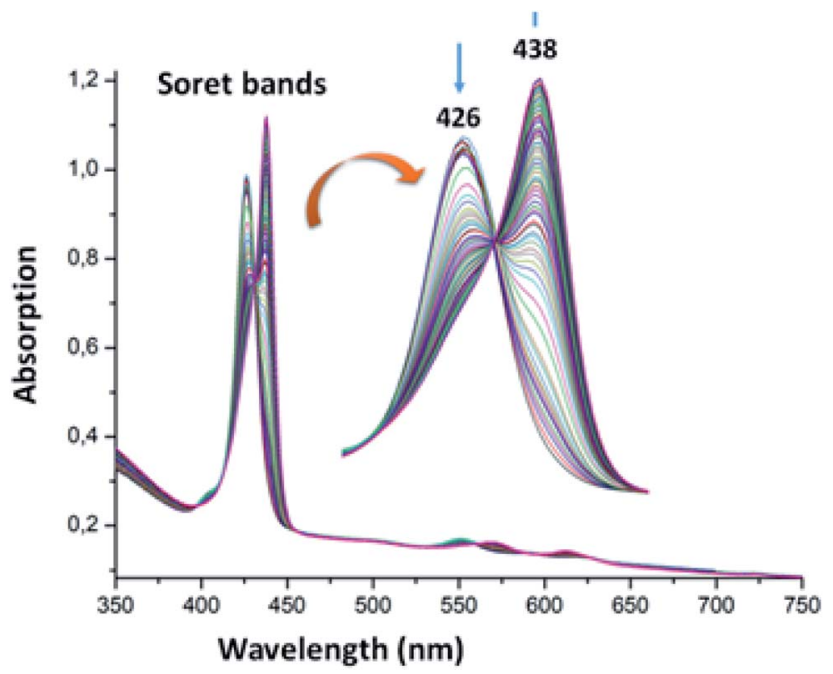

Fig. 5 Changes in the absorption spectra in the Soret band region of complex $5 \mathrm{~b}\left(\sim 10^{-6} \mathrm{M}\right)$ recorded in dichloromethane, upon addition of $\mathrm{Br}^{-}(0-600$ equiv.). The inset shows enlarged view.

Table SI-2. $\dagger$ The values of the amount of MG adsorption calculated from the pseudo second order model are the closest to those determined experimentally for all $\mathbf{4 a - c}$ and $\mathbf{5 a - c}$ porphyrin species, which indicates the adequacy of the use of this model to describe the adsorption phenomenon. The correlation coefficient $\left(R^{2}\right)$ values of the pseudo second order model are close to 0.99. In the case of the pseudo first order model, the $R^{2}$ parameters are between 0.86 and 0.90 for all compounds. For the intraparticle diffusion model, the correlation coefficient does not exceed 0.91 and in the case of Elovich model, the $R^{2}$ values are between 0.93 and 0.97 . These data indicate that the pseudo second order kinetic model is the most appropriate for describing the adsorption of MG dye by our porphyrin derivatives.

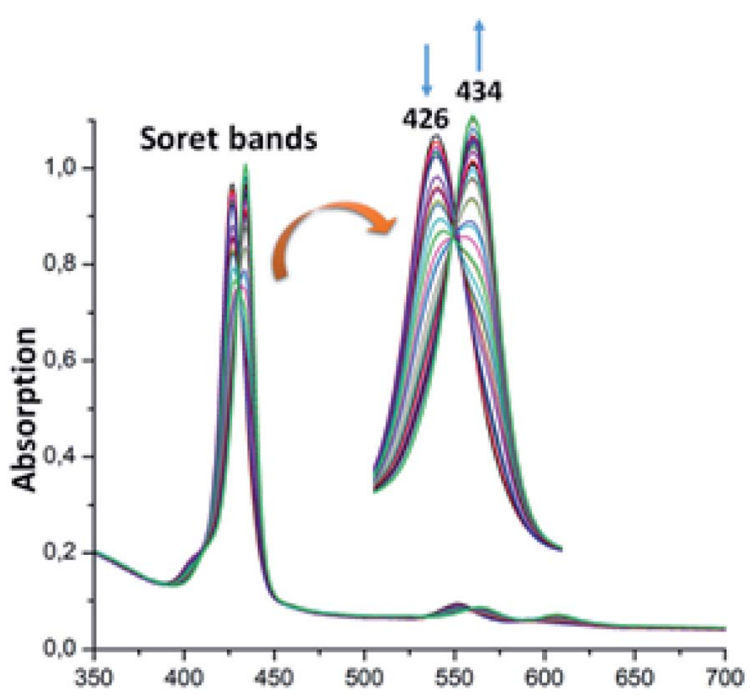

Fig. 6 Changes in the absorption spectra in the Soret band region of complex $5 \mathrm{c}\left(\sim 10^{-6} \mathrm{M}\right)$ recorded in dichloromethane, upon addition of $\mathrm{Cl}^{-}(0-30$ equiv.). The inset shows enlarged view.

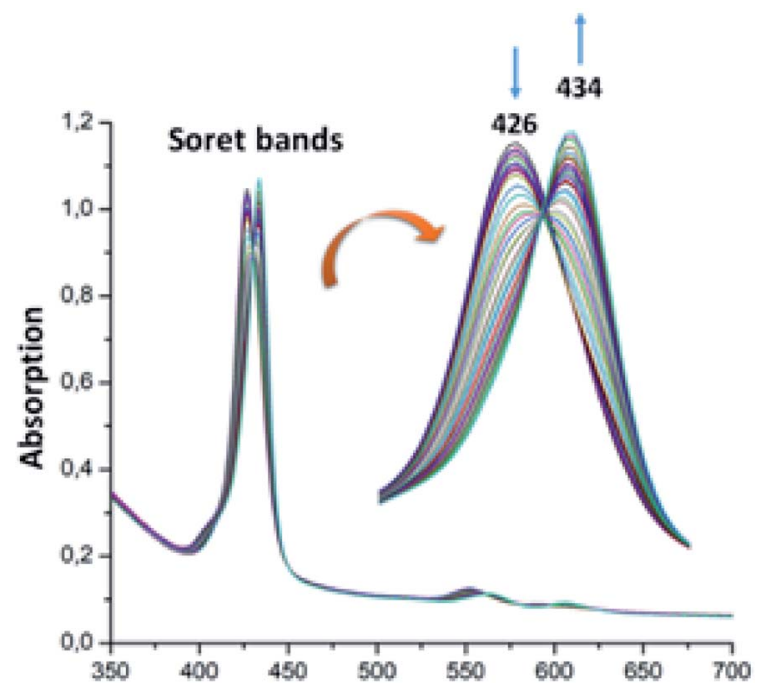

Fig. 7 Changes in the absorption spectra in the Soret band region of complex $5 \mathrm{c}\left(\sim 10^{-6} \mathrm{M}\right)$ recorded in dichloromethane, upon addition of $\mathrm{Br}^{-}(0-30$ equiv.). The inset shows enlarged view.

The second order model equation used is as follows (eqn (5)):

$$
\frac{t}{q_{t}}=\frac{1}{\left(q_{\mathrm{e}}^{2} \times k_{2}\right)}+\frac{t}{q_{\mathrm{e}}}
$$

where, $q_{t}$ and $q_{\mathrm{e}}$ represent the amounts of the adsorbent adsorbed at time $t$ and equilibrium, respectively, while $k_{2}$ is the rate constant for the pseudo second order model ( $\mathrm{g}$ $\left.\mathrm{mg}^{-1} \mathrm{~min}^{-1}\right)$. The values of $k_{2}$ and $q_{\text {cal }}$ were calculated for each of the six porphyrinic compounds from the slope and the intersection of the corresponding plot, respectively.

\subsection{Degradation of MG dye}

2.9.1. Effect of the initial MG concentration. In order to obtain the optimal condition of the initial MG dye concentration, only the 5a derivative was tested. The degradation

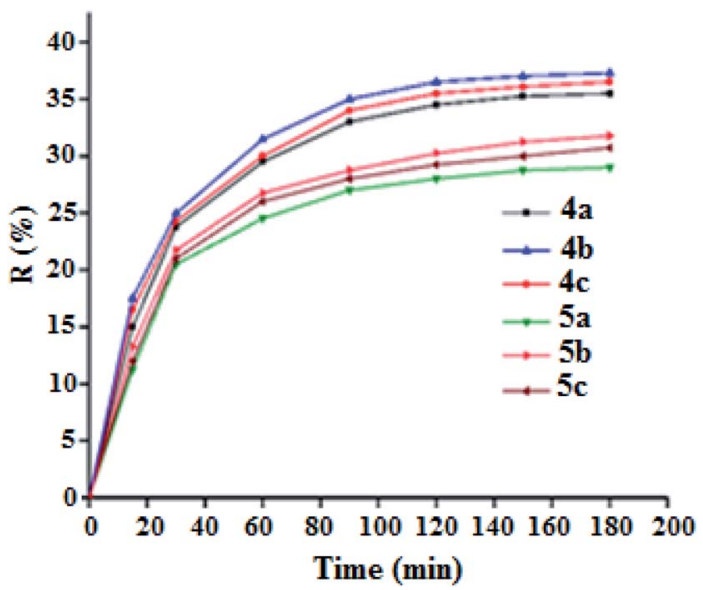

Fig. 8 Adsorption efficiency curves of malachite green dye $\left(C_{0}=\right.$ $20 \mathrm{mg} \mathrm{L}^{-1}$ ) as a function of time of the porphyrin compounds $4 \mathrm{a}-\mathrm{c}$ and $5 \mathrm{a}-\mathrm{c}(m=5 \mathrm{mg}, \mathrm{pH}=8)$. 


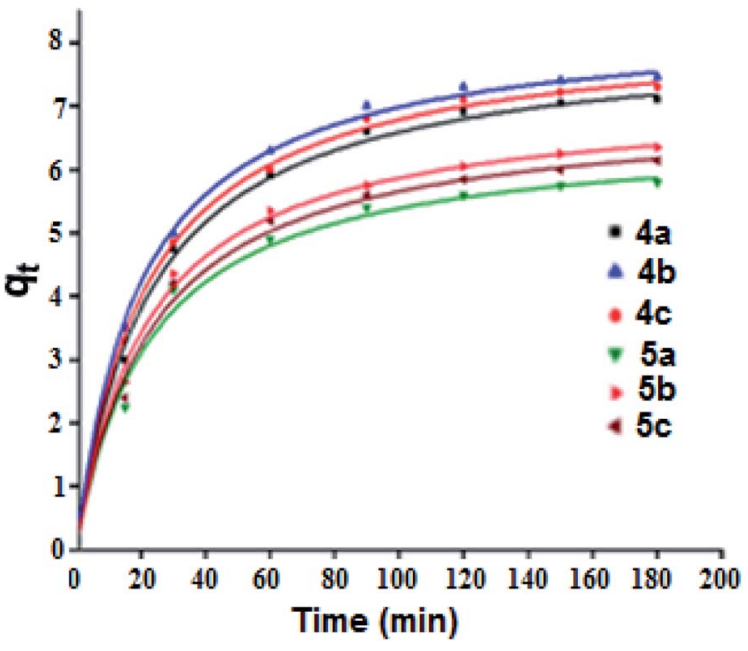

Fig. 9 Adsorption capacity of the $M G$ dye $\left(C_{0}=20 \mathrm{mg} \mathrm{L}^{-1}\right)$ as a function of time for the $4 \mathrm{a}-\mathrm{c}$ and $5 \mathrm{a}-\mathrm{c}$ porphyrin species $(\mathrm{m}=5 \mathrm{mg}$, $\mathrm{pH}=8$ ). Dots represents the experimental data and the curves where plotted using the pseudo second-order kinetic model.

procedure of the MG dye consists of reacting the dye with $\mathrm{H}^{-}$ triazole meso-arylporphyrin zinc(II) (5a) $(m=5 \mathrm{mg})$ in the presence of an aqueous solution of $\mathrm{H}_{2} \mathrm{O}_{2}\left(6 \mathrm{mg} \mathrm{L}^{-1}\right)$ at $\mathrm{pH}=8$. Fig. 10 shows the evolution of the color removal against initial MG dye concentration which shows that the degradation kinetics of MG is slow when the initial dye concentration is increased. This indicates that the increase of the initial concentration of the dye leads to an increase in the number of malachite green molecules, while the number of hydroxyl radicals remains constant. As a consequence, there is a decrease in the kinetics of the degradation reaction as well as the discoloration efficiency. These trends are consistent with those reported in the literature. ${ }^{57}$

2.9.2. Effect of the initial $\mathrm{H}_{2} \mathrm{O}_{2}$ concentration. The 5a triazole zinc(II) derivative was also used to obtain the optimal condition for the initial hydrogen peroxide concentration.

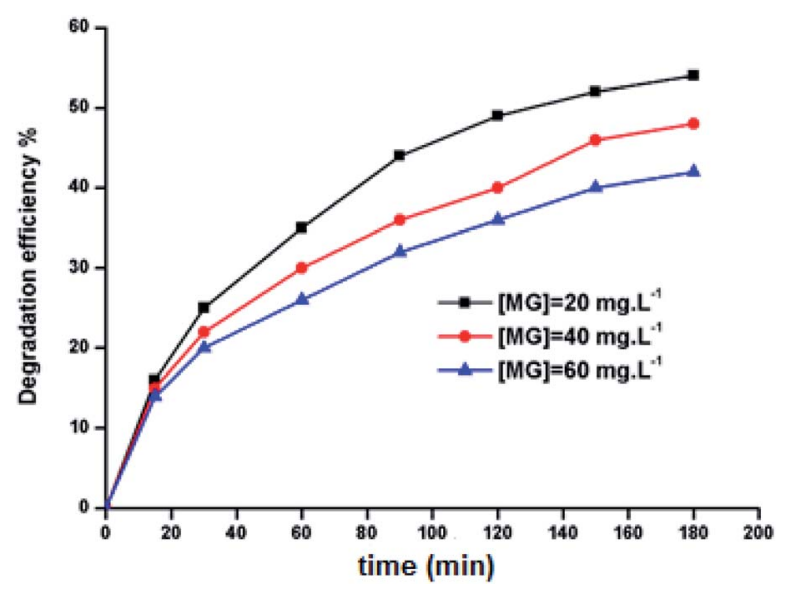

Fig. 10 Evolution of the color removal against initial dye concentration. The hydrogen peroxide concentration, $C_{0}$ is $6 \mathrm{mg} \mathrm{L}^{-1}, 5 a$ catalyst weight $m=5 \mathrm{mg}, \mathrm{pH}=8$ and the MG mass, $m_{\circ}$ is $5 \mathrm{mg}$.

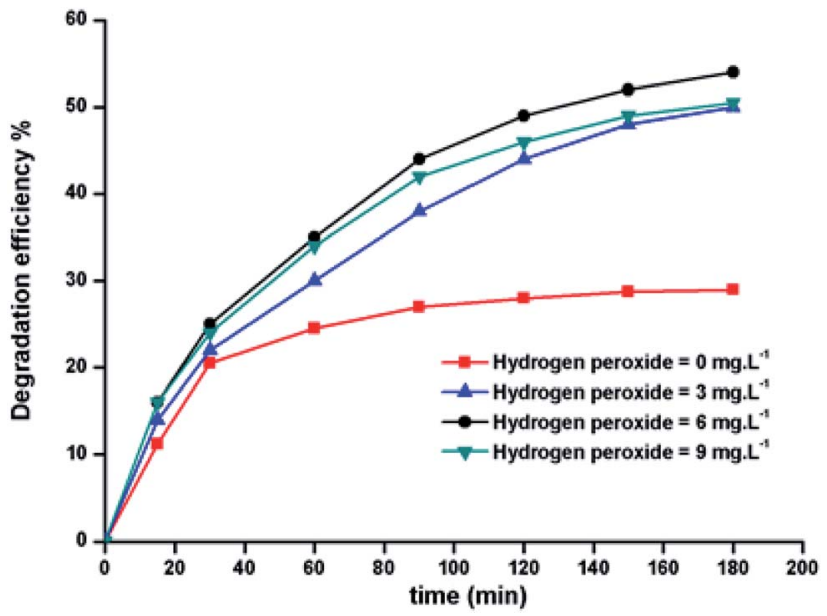

Fig. 11 Change in the degradation efficiency of the MG dye on varying initial $\mathrm{H}_{2} \mathrm{O}_{2}$ concentration using 5 a triazole zinc(I) derivative as a catalyst.

Thus, the effect of the initial hydrogen peroxide concentration $C_{\mathrm{o}}$ on the malachite green dye degradation was studied using an initial MG concentration of $20 \mathrm{mg} \mathrm{L^{-1 }}$ at room temperature using 5a compound as a catalyst. The $C_{\mathrm{o}}$ initial $\mathrm{H}_{2} \mathrm{O}_{2}$ aqueous concentrations used were $0,3,6$ and $9 \mathrm{mg} \mathrm{L}^{-1}$. The increase in $\mathrm{H}_{2} \mathrm{O}_{2}$ concentration from 0 to $6 \mathrm{mg} \mathrm{L}^{-1}$ leads to an increase in the degradation efficiency (Fig. 11). However, for a $C_{\mathrm{o}}$ concentration of $9 \mathrm{mg} \mathrm{L}^{-1}$, the discoloration efficiency of the MG decreases. This phenomenon could be explained by the fact that at high concentration, hydrogen peroxide is a powerful $\mathrm{OH}^{*}$ scavenger $^{58}$ (Equations (eqn (6)-(8)).

$$
\begin{gathered}
\mathrm{H}_{2} \mathrm{O}_{2}+\mathrm{OH}^{-} \rightarrow \mathrm{HO}_{2}^{-}+\mathrm{H}_{2} \mathrm{O} \\
\mathrm{H}_{2} \mathrm{O}_{2}+\mathrm{OH}_{2}^{\cdot} \rightarrow \mathrm{OH}^{\cdot}+\mathrm{O}_{2}+\mathrm{H}_{2} \mathrm{O} \\
\mathrm{HO}_{2}^{\cdot}+\mathrm{OH}^{\cdot} \rightarrow \mathrm{H}_{2} \mathrm{O}+\mathrm{O}_{2}
\end{gathered}
$$

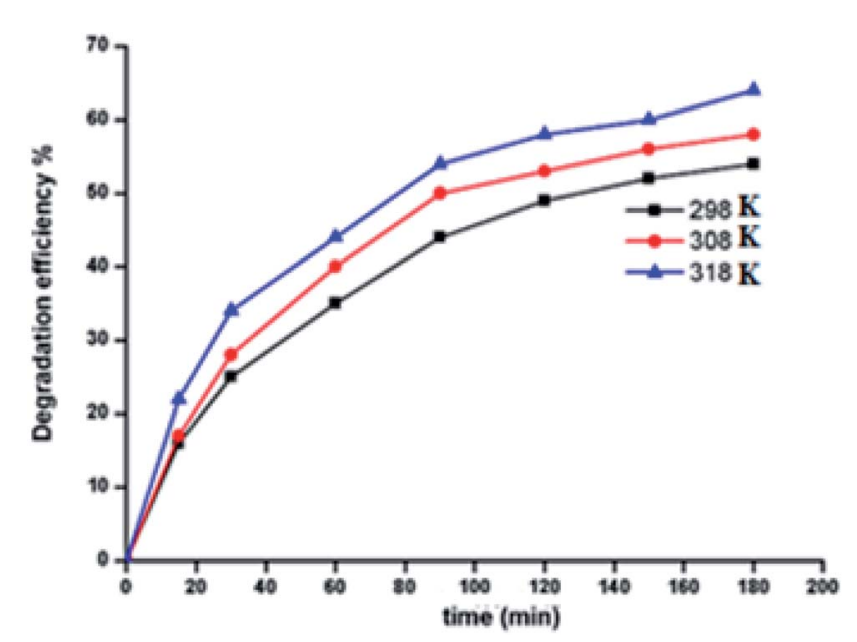

Fig. 12 Change of the degradation efficiency of the MG solution as function of time using $5 \mathrm{a}$ used as catalyst at 298, 308 and $318 \mathrm{~K}$. 
2.9.3. Effects of $\mathbf{p H}$. To investigate the effects of $\mathrm{pH}$ on the degradation of the MG dye by complexes 5a-c, aqueous solutions with $\mathrm{pH}$ from 4 to 8 were adjusted by $0.1 \mathrm{M} \mathrm{HCl}$ and 0.1 $\mathrm{NaOH}$. The influence of $\mathrm{pH}$ on the dye oxidation was studied using five solutions with $\mathrm{pH}$ values determined initially $(4,6,8$, 10 and 12) and without any modifications or control of the $\mathrm{pH}$ during the process. The results obtained for dye removal as a function of the initial $\mathrm{pH}$ of the solution at various reaction times are presented in Fig. SI-18. $\dagger$ The maximum conversion was achieved after $3 \mathrm{~h}$ from the start of the reaction for a $\mathrm{pH}$ of 8.

2.9.4. Degradation with optimal conditions. The degradation study of the MG dye was carried out using an aqueous $\mathrm{H}_{2} \mathrm{O}_{2}$ solution under optimal conditions, found for the 5 a derivative, and applied to the two other species 5b-c (Fig. SI-19b and c $\dagger$ ).
Fig. SI-19a $\dagger$ represents the absorption curve of the MG dye in presence of $\mathrm{H}_{2} \mathrm{O}_{2}$ without catalyst (blank experiment) versus time where it can be seen that the absorption remains practically the same for a period of $180 \mathrm{~min}$. By using the same mass of the three catalysts $\mathbf{5 a - c}$, the obtained degradation yields are $54.0,52.1$ and $48.9 \%$ for $\mathbf{5 a}, \mathbf{5 b}$ and $\mathbf{5 c}$, respectively (Fig. SI$20 \mathrm{a} \dagger)$. The degradation reactions were achieved after $180 \mathrm{~min}$. Fig. SI-20b $\dagger$ shows the degradation removal efficiency for complexes 5a-c using the same number of moles $(3.35 \times$ $10^{-6}$ mol.) for the three species. The obtained degradation

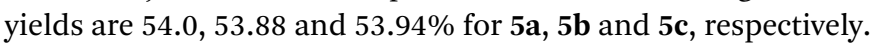
These results show that using the same number of moles for our three 5a-c catalysts, the degradation efficiency is virtually the same $(\sim 54 \%)$. This confirms the fact that the central metal is the main site of degradation of the dye $\mathrm{e}^{58}$ and that the nature of the substituent $\mathrm{X}(\mathrm{X}=\mathrm{H}, \mathrm{Cl}$ and $\mathrm{I})$ on the para-position of the

Table 5 Selection of several methods used for MG degradation with the optimal reaction conditions and yields

\begin{tabular}{|c|c|c|c|}
\hline Chemical method: Fenton's reagent & $\begin{array}{l}\mathrm{Fe}(\mathrm{II}) / \text { aqueous } \mathrm{H}_{2} \mathrm{O}_{2}, \mathrm{pH}=3.4, \\
{\left[\mathrm{H}_{2} \mathrm{O}_{2}\right]_{\mathrm{o}}=0.50 \mathrm{mM},\left[\mathrm{Fe}^{2+}\right]=} \\
0.10 \mathrm{mM},[\mathrm{MG}]_{0}=20 \mathrm{mg} \mathrm{L}^{-1}, 30{ }^{\circ} \mathrm{C}\end{array}$ & $99.25 \%(60 \mathrm{~min})$ & 60 \\
\hline $\begin{array}{l}\text { Chemical method: mesoporous } \\
\text { carbon adsorbent }\end{array}$ & $\begin{array}{l}\text { Mesoporous silica (MCM-48), } \mathrm{pH}= \\
8.5,\left[\text { silica] }=5.10^{-3} \mathrm{~g} / 25 \mathrm{~mL},[\mathrm{MG}]_{0}\right. \\
=50 \mathrm{mg} \mathrm{L}^{-1}, T=25{ }^{\circ} \mathrm{C}\end{array}$ & $98.2 \%(30 \mathrm{~min})$ & 61 \\
\hline Photocatalysis method & $\begin{array}{l}\mathrm{Ag} \text { doped } \mathrm{TiO}_{2}, \mathrm{pH}=9,[\mathrm{MG}]_{0}=5 \times \\
10^{-6} \mathrm{M},[\text { catalyst }]=0.12 \mathrm{~g}, 60 \mathrm{~mW} \\
\mathrm{~cm}^{-2} \text { light intensity }\end{array}$ & $99.5 \%$ & 63 \\
\hline Biodegradation method & $\begin{array}{l}\text { System used: Pseudomonas sp. } \\
\text { strain DY1, }\left[\mathrm{MG}_{\mathrm{o}}\right]=100- \\
1000 \mathrm{mg} \mathrm{L}^{-1}, \mathrm{pH}=6.6, T=28-30^{\circ} \mathrm{C}\end{array}$ & Effective decolorization: $78.9-84.3 \%$ & 65 \\
\hline
\end{tabular}

Use of our three zinc(II) complexes 5a-c

\begin{tabular}{|c|c|c|}
\hline Complex & System used & Yield \\
\hline$\left[\mathrm{Zn}\left(\mathrm{T}_{\mathrm{AzP}}-\mathrm{HVP}\right)\right] \mathbf{5 a}$ & $\begin{array}{l}{\left[\mathrm{H}_{2} \mathrm{O}_{2}\right]=C_{\mathrm{o}}=6 \mathrm{mg} \mathrm{L}^{-1},[\mathrm{MG}]=20 \mathrm{mg} \mathrm{L}^{-1},} \\
\text { weight of catalyst }(\mathbf{5 a})=m_{\mathrm{o}}=5 \mathrm{mg}, \mathrm{pH}=8, T \\
=25{ }^{\circ} \mathrm{C}\end{array}$ & $54.0 \%(180 \mathrm{~min})$ \\
\hline$\left[\mathrm{Zn}\left(\mathrm{T}_{\mathrm{Az}}-\mathrm{ClVP}\right)\right] \mathbf{5 b}$ & $\begin{array}{l}{\left[\mathrm{H}_{2} \mathrm{O}_{2}\right]=C_{\mathrm{o}}=6 \mathrm{mg} \mathrm{L}^{-1},[\mathrm{MG}]=20 \mathrm{mg} \mathrm{L}^{-1},} \\
\text { weight of catalyst }(\mathbf{5 b})=m_{\mathrm{o}}=5 \mathrm{mg}, \mathrm{pH}=8, T \\
=25{ }^{\circ} \mathrm{C}\end{array}$ & $52.0 \%(180 \mathrm{~min})$ \\
\hline
\end{tabular}


terminal phenyl of the three triazole meso-aryporphyrins $\mathbf{4 a - c}$, practically has no effect on this degradation.

2.9.5. Effect of temperature. For the zinc(II) porphyrin derivative $5 \mathbf{a}$, the effect of temperature on the degradation of MG dye has been investigated. The temperatures used were 25, 35 and $45{ }^{\circ} \mathrm{C}$ (Fig. 12). As expected, the degradation efficiency of MG dye increased from $54.0 \%$ to $64.2 \%$ as a consequence of increasing the temperature from 25 to $45{ }^{\circ} \mathrm{C}$. This is due to the fact that higher temperatures increase the reaction rate between hydrogen peroxide and the zinc metal center. This in turn increases the rate of generation of the $\mathrm{OH}^{\cdot}$ radical oxidizing species. ${ }^{59}$

2.9.6. Comparison of our procedure with other reported methods. Many investigations concerning the MG degradation have previously been reported in the literature. ${ }^{19}$ The most important of which are: the chemical methods, the photocatalysis methods and the biodegradation methods (Table 5).

As depicted in Table 5, the degradation yields of the MG dye obtained using our zinc(II) 5a-c $(\sim 50 \%)$ porphyrin zinc(II) complexes are lower than those obtained using the other methods shown in this table. It is expected that the use of other metal ions instead of $\mathrm{Zn}$ (II), such as $\mathrm{Cu}$ (II) or $\mathrm{Fe}(\mathrm{II})^{\mathbf{6 0}}$ with our three triazole porphyrins in the presence of $\mathrm{H}_{2} \mathrm{O}_{2}$ will lead to an increase in the degradation efficiency of the dye. This is due to the fact that ferrous and cuprous ions are more effective than $\mathrm{Zn}^{2+}$ ion in giving $\mathrm{HO}_{2}^{\circ}$ and $\mathrm{OH}^{-}$radicals.

Nevertheless, the obtained yields are quite acceptable for a first reported investigation on the MG degradation using a porphyrin derivative. Thus, these encouraging results suggest that our zinc(II) 5a-c can be further improved and can be concomitantly used with other degradation techniques such as the photodegradation where the expected yields are higher than those reported here.

2.9.7. Activation energy and thermodynamic variables. To better understand the degradation phenomenon, the pseudo first order model was used to calculate the kinetic parameters. Arrhenius law (eqn (9)) was used to determine the activation energy $\left(E_{\mathrm{a}}\right)$. The thermodynamic activation parameters of enthalpy $\left(\Delta H^{*}\right)$, entropy $\left(\Delta S^{*}\right)$ and Gibbs free energy $\left(\Delta G^{*}\right)$ were calculated using Eyring's equation (eqn (10) and (11)). ${ }^{66}$

$$
\begin{gathered}
\ln k_{\mathrm{o}}=\ln A_{\mathrm{o}}-\frac{E_{\mathrm{a}}}{R T} \\
\ln \left(\frac{k_{\mathrm{o}}}{T}\right)=\ln \left(\frac{k}{h}\right)+\frac{\Delta S^{*}}{R}-\frac{\Delta H^{*}}{R T} \\
\Delta G^{*}=\Delta H^{*}-T \Delta S^{*}
\end{gathered}
$$

where $k_{\mathrm{o}}$ is the kinetic rate, $h$ and $k$ are the Plank's and Boltzmann's constants, respectively. $A_{\mathrm{o}}$ is the Arrhenius constant and $R$ is the universal gas constant $\left(8.314 \mathrm{~J} \mathrm{~mol}^{-1} \mathrm{~K}^{-1}\right)$. The obtained thermodynamic parameters and activation energy values are summarized in Table 6. From these results, it can be seen that the free energy is positive in all the cases. This indicates that the degradation of MG dye using $\mathrm{H}_{2} \mathrm{O}_{2}$ is a non-spontaneous reaction regardless of temperature. The free enthalpy is positive,
Table 6 Thermodynamic parameters $\left(\Delta S^{*}, \Delta H^{*}, \Delta G^{*}\right)$ and activation energy $\left(E_{a}\right)$ for complex $5 a$

\begin{tabular}{llll}
\hline$T\left({ }^{\circ} \mathrm{C}\right)$ & 25 & 35 & 45 \\
$k_{\mathrm{o}}\left(\mathrm{min}^{-1}\right)$ & 0.0042 & 0.0046 & 0.0054 \\
$E_{\mathrm{a}}\left(\mathrm{kJ} \mathrm{mol}^{-1}\right)$ & 9.867 & 9.867 & 9.867 \\
$\Delta S^{*}\left(\mathrm{~J} \mathrm{~mol}^{-1} \mathrm{~K}^{-1}\right)$ & -265.983 & -265.983 & -265.983 \\
$\Delta H^{*}\left(\mathrm{~kJ} \mathrm{~mol}^{-1}\right)$ & 7.308 & 7.308 & 7.308 \\
$\Delta G^{*}\left(\mathrm{~kJ} \mathrm{~mol}^{-1}\right)$ & 86.570 & 89.230 & 91.890
\end{tabular}

meaning the degradation process is endothermic and a higher temperature facilitates degradation. The negative value of the entropy suggests the diminution of the disorder during the degradation process. The activation energy value is $9.867 \mathrm{~kJ} \mathrm{~mol}^{-1}$. Since the thermodynamic parameters found for both 5b-c complexes are very close to those of complex 5a, only the results founds for the latter zinc(II) derivative are reported.

\section{Conclusion}

We have successfully synthesized three novel triazole mesoarylporphyrins, the: H-triazole, chloro-triazole and iodine-triazole meso-arylporphyrins with the respective formulas $\mathrm{H}_{2}\left(\mathrm{~T}_{\mathrm{AzP}}-\right.$ HVP) (4a), $\mathrm{H}_{2}\left(\mathrm{~T}_{\mathrm{AzP}}-\mathrm{ClVP}\right)$ (4b) and $\mathrm{H}_{2}\left(\mathrm{~T}_{\mathrm{AzP}}-\mathrm{IVP}\right)$ (4c) as well as their corresponding zinc(II) porphyrins 5a-c. The chloride and bromide binding properties of the chloro-triazole and the iodine-triazole zinc(II) triazole meso-arylporphyrins derivatives $\mathbf{5 b}-\mathbf{c}$ have been monitored by UV-visible technique. Both $\mathbf{5 b}$-c receptors exhibit strong $\mathrm{Cl}^{-}$and $\mathrm{Br}^{-}$anion binding affinities, forming 1:1 stoichiometric complexes. The adsorption efficiency of the malachite green dye (MG) on all three base porphyrins and their corresponding zinc(II) coordination compounds revealed that: (i) the adsorption efficiency of the free base porphyrins $\mathbf{4 a - c}$ are higher than those of the corresponding zinc(II) porphyrin complexes $\mathbf{5 a - c}$, (ii) the free base chloro-triazole and iodine-triazole $\mathbf{4 b}$-c porphyrin derivatives show better adsorption than that of the $\mathrm{H}$-triazole $\mathrm{T}_{\mathrm{AzP}}-\mathrm{HVP}$ species (4a), which is also the case for the corresponding zinc(II) porphyrin complexes (5a-c) and (iii), the pseudo second order kinetic model is the most appropriate to describe the adsorption of MG dye by our free porphyrin compounds. The degradation investigation of the MG dye, using complexes $5 \mathbf{a}-\mathbf{c}$ as catalysts, carried out using an aqueous $\mathrm{H}_{2} \mathrm{O}_{2}$ solution under optimal conditions, shows that the degradation yield using the $\mathrm{H}$-triazole meso-arylporphyrin zinc(II) derivative $\mathbf{5 a}$ is higher than those of the chloro-triazole and the iodine-triazole mesoarylporphyrin zinc(II) complexes 5b-c. The degradation yields using our 5a-c species are $\sim 54 \%$ which are much smaller than several reported MG dye degradations using other methods. Nevertheless, this is an encouraging result as this is the first time a porphyrin derivative has been used for the degradation of this dye and studies are underway to test our zinc(II) derivatives in photochemical degradations of the malachite green and other dyes. The thermodynamic parameters were determined and show that the free energy is positive in all the cases indicating that the degradation of $\mathrm{MG}$ dye using $\mathrm{H}_{2} \mathrm{O}_{2}$ is a non- 
spontaneous, temperature-dependent reaction. Furthermore, the enthalpy is positive which implies that the degradation process is endothermic, while the negative value of the entropy suggests the diminution of disorder during the degradation process.

\section{Conflicts of interest}

There are no conflicts to declare.

\section{Acknowledgements}

The authors extend their appreciation to the deanship of Scientific Research at Majmaah University, Saudi Arabia.

\section{References}

1 M. Pineiro, A. L. Carvalho, M. M. Pereira, A. M. d'A. R. Gonsalves, L. G. Arnaut and S. J. Formosinho, Chem.-Eur. J., 1998, 2299-2307.

2 X. I. Liang, X. Li and X. Yue, Angew. Chem., Int. Ed., 2011, 50, 11622-11627.

3 S. Lin, C. S. Diercks, Y.-B. Zhang, N. Kornienko, E. M. Nichols, Y. Zhao, A. R. Paris, D. Kim, P. Yang, O. M. Yaghi and C. J. Chang, Science, 2015, 349, 1208-1213. 4 H. Imahori, S. Hayashi, H. Hayashi, A. Oguro, S. Eu, T. Umeyama and Y. Matano, J. Phys. Chem. C, 2009, 113, 18406-18413.

5 M. Florescu and M. David, Sensors, 2017, 17, 1-16.

6 A. Colombelli, M. G. Manera, V. Borovkovb, G. Giancanec, L. Valli and R. Rell, Sens. Actuators, B, 2017, 246, 1039-1048.

7 E. Aguilar-Ortíz, N. Lévaray, M. Vonlanthen, E. G. MoralesEspinoza, Y. Rojas-Aguirre, X. X. Zhu and E. Rivera, Dyes Pigm., 2016, 132, 110-120.

8 B. M. J. M. Suijkerbuijk and R. J. M. Gebbink, Angew. Chem., Int. Ed. Engl., 2008, 47, 7396-7421.

9 W. Auwärter, D. Écija, F. Klappenberger and J. V. Barth, Nat. Chem., 2015, 7, 105-120.

10 J. M. Gottfried, Surf. Sci. Rep., 2015, 70, 259-279.

11 H. C. Kolb, M. G. Finn and K. B. Sharpless, Angew. Chem., Int. Ed., 2001, 40, 2004-2021.

12 L. C. Gilday, N. G. White and P. D. Beer, Dalton Trans., 2012, 41, 7092-7097.

13 L. C. Gilday, N. G. White and P. D. Beer, Dalton Trans., 2013, 42, 15766-15773.

14 M. Ismail, K. Akhtar, M. I. Khan, T. Kamal, M. A. Khan, A. M. Asiri, J. Seo and S. B. Khan, Curr. Pharm. Des., 2019, 25, 3653-3671.

15 K. Su Min, R. Satish Kumar, J.-H. Lee, K. S. Kim, S. G. Lee and Y.-A. Son, Dyes Pigm., 2019, 160, 37-47.

16 Y. Li, L. Wang, Y. Gao, W. Yang, Y. Lia and C. Guo, RSC Adv., 2018, 8, 7330-7339.

17 M. Guergueb, S. Nasri, J. Brahmi, F. Loiseau, F. Molton, T. Roisnel, V. Guerineau, I. Turowska-Tyrk, K. Aouadi and H. Nasri, RSC Adv., 2020, 10, 6900-6918.
18 R. Soury, M. Jabli, T. A. Saleh, W. S. Abdul-Hassan, E. SaintAman, F. Loiseau, C. Philouze and H. Nasri, RSC Adv., 2018, 8, 20143-20156.

19 P. N. P. Raval, P. U. Shah and N. K. Shah, Appl. Water Sci., 2017, 7, 3407-3445.

20 S. Srivastava, R. Sinha and D. Roy, Aquat. Toxicol., 2004, 66, 319-329.

21 S.-Y. An, S.-K. Min, I.-H. Cha, Y.-L. Choi, Y.-S. Cho, C.-H. Kim and Y.-C. Lee, Biotechnol. Lett., 2002, 24, 1037-1040.

22 J. Brahmi, K. Aouadi, M. Msaddek, J.-P. Praly and S. Vidal, C. R. Chim., 2016, 19, 933-935.

23 A. D. Adler, F. R. Longo, J. D. Finarelli, J. Goldmacher, j. Assour and L. J. Korsakoff, Org. Chem., 1967, 32, 476.

24 S. Nasri, I. Zahou, I. Turowska-Tyrk, T. Roisnel, F. Loiseau, E. Saint-Amant and H. Nasri, Eur. J. Inorg. Chem., 2016, 5004-5019.

25 K. Görlitzer, S. Huth and P. G. Jones, Pharmazie, 2005, 60, 269-272.

26 K. Ezzayani, Z. Denden, S. Najmudin, C. Bonifácio, E. SaintAman, F. Loiseau and H. Nasri, Eur. J. Inorg. Chem., 2014, 5348-5361.

27 C. C. Mak, N. Bampos and J. K. M. Sanders, Angew Chem. Int. Ed., 1998, 37, 3020-3023.

28 H. M. Zeyada, M. M. Makhlouf and M. A. Ali, Jpn. J. Appl. Phys., Part 1, 2016, 55, 022601.

29 C.-I. Lin, M.-Y. Fang and S.-H. Cheng, J. Electroanal. Chem., 2002, 531, 155-162.

30 P. Tao, A. Viswanath, L. S. Schadler, B. C. Benicewicz and R. W. Siegel, ACS Appl. Mater. Interfaces, 2011, 3, 3638-3645.

31 P. Singh, A. Kaushal and D. Kaur, J. Alloys Compd., 2009, 471, 11-15.

32 K. M. Barkigia, M. D. Berber, J. Fajer, C. J. Medforth, M. W. Renner and K. M. Smith, J. Am. Chem. Soc., 1990, 112, 8851-8854.

33 J. Zhang, P. Zhang, Z. Zhang and X. J. Wei, J. Phys. Chem. A, 2009, 113, 5367-5374.

34 M. Gouterman, J. Mol. Spectrosc., 1961, 6, 138-163.

35 C. C. Mak, N. Bampos and J. K. M. Sanders, Angew. Chem., Int. Ed., 1998, 37, 3020-3022.

36 Z. Denden, K. Ezzayani, E. Saint-Aman, F. Loiseau, S. Najm, Bonifácio, J.-C. Daran and H. Nasri, Eur. J. Inorg. Chem., 2015, 2596-2610.

37 D. Kim and E. J. Shin, Bull. Korean Chem. Soc., 2003, 24, 1490-1494.

38 S. Neya and N. Funasaki, Tetrahedron Lett., 2002, 43, 10571058.

39 D. J. Quimby and F. R. Longo, J. Am. Chem. Soc., 1975, 97, 5111-5117.

40 K. M. Kadish and M. M. Morrison, J. Am. Chem. Soc., 1976, 98, 3326-3328.

41 C.-I. Lin, M.-Y. Fang and S.-H. Cheng, J. Electroanal. Chem., 2002, 531, 155-162.

42 A. Ghosh, S. M. Mobin, R. Fröhlich, R. J. Butcher, D. K. Maity and M. Ravikanth, Inorg. Chem., 2010, 49, 8287-8297.

43 J. L. Bredas, R. Silbey, D. S. Bordeaux and R. R. Chance, J. Am. Chem. Soc., 1983, 105, 6555-6559. 
44 D. M. Lyons, J. Kesters, W. Maes, W. Christopher, J. Bielawski and L. Sessler, Synth. Met., 2013, 178, 56-61.

45 K. M. Kadish, P. Chen, Y. Yu. Enakieva, S. E. Nefedov, Y. G. Gorbunova, A. Y. Tsivadze, A. BessmertnykhLemeune, C. Stern and R. Guilard, J. Electroanal. Chem., 2011, 656, 61-71.

46 K. M. Barkigia, L. Chantranupong, K. M. Smith and J. Fajer, J. Am. Chem. Soc., 1988, 110, 7566-7567.

47 J. A. Shelnutt, in The Porphyrin Handbook, ed. K. M. Kadish, K. M. Smith and R. Guilard, Academic Press, San Diego, 2000, vol. 7, pp. 167-223.

48 A. Ozarowski, H. M. Lee and A. L. Balch, J. Am. Chem. Soc., 2003, 125, 12606-12614.

49 J. Polster and H. Lachmann Spectrometric Titrations, Verlag Chemie, Weinheim, 1989, p. 292.

$50 \mathrm{~S}$. U. Khan, Fundamental aspects of pollution control and environmental Science, Elsevier, New York, 1980.

51 N. Senesi and Y. Chen, Ecological Studies, ed. Z. Gerstl, Y. Chen, U. Mingelgril and B. Yaron, Sringer verglag, Berlin, 1989, pp. 37-90.

52 S. Chowdhury and P. Das, Sep. Sci. Technol., 2011, 46, 19661976.

53 D. A. Dzombak and R. G. Luthy, Soil Sci., 1984, 137, 292-308.

54 C. T. Chiou, L. J. Peters and V. H. Freed, Science, 1979, 206, 831-832.
55 N. B. Swan and M. A. A. Zaini, Ecol. Chem. Eng. S, 2019, 26, 119-132.

56 H. Qui, L. Lv, B.-C. Pan, Q.-J. Zhang, W.-M. Zhang and Q.-X. Zhang, J. Zhejiang Univ., Sci., A, 2009, 10, 716-724.

57 B. H. Hameed and T. W. Lee, J. Hazard. Mater., 2009, 164, 468-472.

58 R. Aravindhan, N. N. Fathima, J. R. Rao and B. U. Nair, J. Hazard. Mater., 2006, B138, 152-159.

59 J. H. Sun, S. P. Sun, G. L. Wang and L. P. Qiao, Dyes Pigm., 2007, 74, 647-652.

60 B. H. Hameed and T. W. Lee, J. Hazard. Mater., 2009, 164, 468-472.

61 M. Anbia and A. Ghaffari, J. Iran. Chem. Soc., 2012, 8, 67-76.

62 A. S. Hussein and N. Y. Fairooz, Journal of University of Babylon for Pure and Applied Sciences, 2016, 9, 2510-2518.

63 H. R. Khan, M. A. Choudhary, M. A. Mirza, Z. Ahmed and Y. Khan, Asian J. Chem., 2017, 29, 257-260.

64 T. Mukherjee and M. Das, Clean: Soil, Air, Water, 2014, 42, 849-856.

65 L.-N. Du, S. Wang, G. Li, B. Wang, X.-M. Jia, Y.-H. Zhao and Y.-L. Chen, Ecotoxicology, 2011, 20, 438-446.

66 B. A. Fil, M. T. Yilmaz, S. Bayar and M. T. Elkoca, Braz. J. Chem. Eng., 2014, 31, 171-182. 